\title{
Synthesis and Complexation of a Free Germanide Bearing a Tridentate N-Heterocyclic Substituent
}

\author{
Léon Witteman, ${ }^{\dagger}$ Cody B. van Beek, ${ }^{\dagger}$ Oscar N. van Veenhuizen, ${ }^{\dagger}$ Martin Lutz,
} and Marc-Etienne Moret* ${ }^{*} \dagger$

\begin{abstract}
${ }^{\dagger}$ Department of Chemistry, Debye Institute for Nanomaterials Science Utrecht University, Universiteitsweg 99, 3584 CG Utrecht, The Netherlands

${ }^{\ddagger}$ Crystal and Structural Chemistry, Bijvoet Center for Biomolecular Research, Faculty of Science, Utrecht University, Padualaan 8 , $3584 \mathrm{CH}$ Utrecht, The Netherlands
\end{abstract}

Supporting Information

ABSTRACT: The tris-N-heterocycle germanide (tmim) $\mathrm{Ge}^{-}$ (1) $\left(\mathrm{tmimH}_{3}=\operatorname{tris}(3-\right.$ methylindol-2-yl)methane) was synthesized by nucleophilic substitution for the $\mathrm{tmim}^{3-}$ trianion on $\mathrm{GeCl}_{2}$-dioxane. In combination with the previously reported (tmim) $\mathrm{Si}^{-}$and (tmim) $\mathrm{P}$ analogues, it provides a convenient model for investigating the influence of the central atom on the properties of isoelectronic ligands. Complexation of the germanide (tmim) $\mathrm{Ge}^{-}$to $\mathrm{CuCl}$ resulted in the dimeric chloro cuprate $[(\mathrm{tmim}) \mathrm{GeCu}(\mu-\mathrm{Cl})]_{2}{ }^{2-}$, which is prone to dissociation in $\mathrm{MeCN}$ to form the neutral, solvated germylcopper (tmim) $\mathrm{GeCu}(\mathrm{NCMe})_{3}$. The reaction of 1 with $\mathrm{Fe}_{2}(\mathrm{CO})_{9}$ afforded the germyl iron tetracarbonyl $\left[(\mathrm{tmim}) \mathrm{GeFe}(\mathrm{CO})_{4}\right]^{-}$. Analysis of the $\tilde{\nu}(\mathrm{CO})$ infrared absorption bands in this

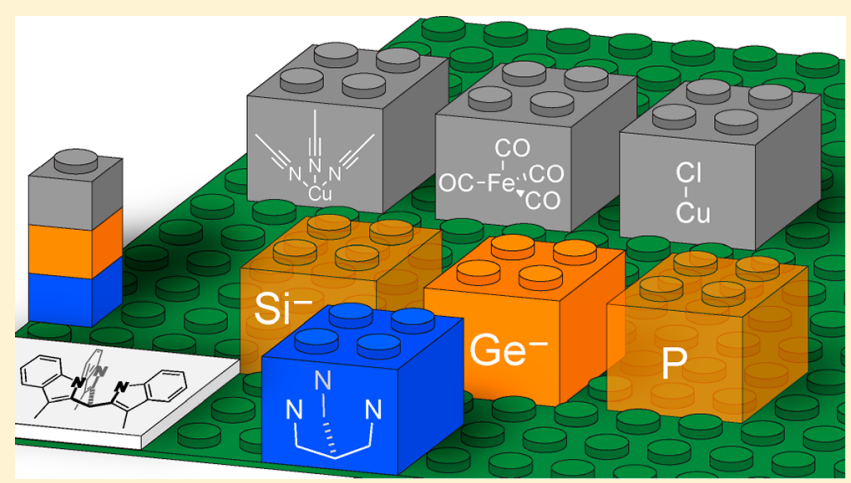
complex indicates that the combined electron donating and accepting properties of 1 are found in between those of (tmim) $\mathrm{P}$ and (tmim) $\mathrm{Si}^{-}$. In contrast to (tmim) $\mathrm{Si}^{-},(\mathrm{tmim}) \mathrm{Ge}^{-}$is reluctant to coordinate to $\mathrm{FeCl}_{2}$, likely because of its softer Lewis base character. Key structural features of the ligands and complexes reflect changes in their electronic properties. In particular, the $\mathrm{N}-\mathrm{Ge}-\mathrm{N}$ angles increase upon coordination to a metal fragment, suggesting increasing hybridization of the Ge s- and $\mathrm{p}-$ orbitals. These findings will be useful in further understanding low-valent heavier group 14 complexes in organometallic chemistry.

\section{INTRODUCTION}

Ligands based on the heavier analogues of carbenes have received considerable interest in recent years. ${ }^{1-3}$ A large fraction of known $\mathrm{Si}(\mathrm{II})$ and $\mathrm{Ge}(\mathrm{II})$ species are base-stabilized silylenes or germylenes, i.e., compounds featuring two anionic and at least one donating, neutral substituent. Such compounds can serve as ligands for a broad range of transition metals, and transition-metal complexes of silylene $e^{4-11}$ and germylene ${ }^{5,6,10}$ ligands are finding applications in catalysis. $\mathrm{Ge}(\mathrm{II})$ compounds are generally less reducing than their $\mathrm{Si}$ (II) counterparts and hence more easily accessible, largely because $\mathrm{Ge}(\mathrm{II})$ precursors such as $\mathrm{GeCl}_{2}$. dioxane are readily available. Because of their similar covalent radii (Si: 1.11(2) A and Ge: $1.20(4) \AA),{ }^{12} \mathrm{Si}(\mathrm{II})$ and $\mathrm{Ge}(\mathrm{II})$ often give rise to similar structures and parallel reactivity, but instructive differences are known. For example, Aquino et al. investigated the electronic properties, e.g., Brønsted acidity, of zwitterionic silylsubstituted methanides, silanides, and germanides $\left(\mathrm{R}_{3} \mathrm{E}(\mathrm{II})\right.$ anions), showing that basicity decreases down group 14 (Scheme 1, A). ${ }^{13}$ They also note that the methanides are markedly different from the silanides and germanides, both structurally and electronically, mainly due to significant hyperconjugation of the lone pair into the adjacent silyl groups. The decreased basicity also translates in increased stability of $\mathrm{E}$ (II) compounds going down group 14. For example, the mere existence of compounds of type $\mathrm{X}_{2} \mathrm{E}(\mathrm{X}=$ halo, $\left.\mathrm{N}\left(\mathrm{SiMe}_{3}\right)_{2}\right)$ for $\mathrm{E}=\mathrm{Ge}(\mathrm{II}), \mathrm{Sn}(\mathrm{II})$ illustrates this difference, as the $\mathrm{Si}(\mathrm{II})$ homologues decompose well below ambient temperature. The stability of these germylenes and stannylenes is due to the increasing energy separation of the central atom's s- and p-orbitals, descending group $14 .^{14-18}$

Another illustrative example is the addition of small molecules over the $\beta$-diketiminato silylene or germylene (Scheme 1, B). Despite their structural resemblance, the silylene showed a thermodynamic preference for 1,1-addition and formal oxidation of $\mathrm{Si}$ (II) to $\mathrm{Si}(\mathrm{IV})$, whereas, in the germylene, 1,4-addition was preferred, transforming the diamido-germylene center in a base-stabilized amido(triflate)germylene. ${ }^{19-21}$ Finally, the catalytic activity of homologous silylene and germylene complexes has been compared. In hydroformylation catalysis, a rhodium complex of a ferrocene-

Received: August 30, 2018

Published: January 9, 2019 
Scheme 1. (A) Group 14 Anions Used for Brønsted Acidity Determination. ${ }^{13}$ (B) Contrasting Reactivity between Structurally Similar Silylene and Germylene. ${ }^{19-21}$ (C) Catalytically Active Complexes of Silylene and Germylene Ligands and of a Related Phosphine Ligand ${ }^{5 a, 6,10,22}$

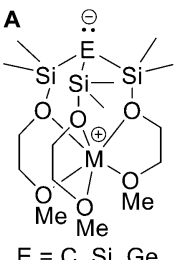

B
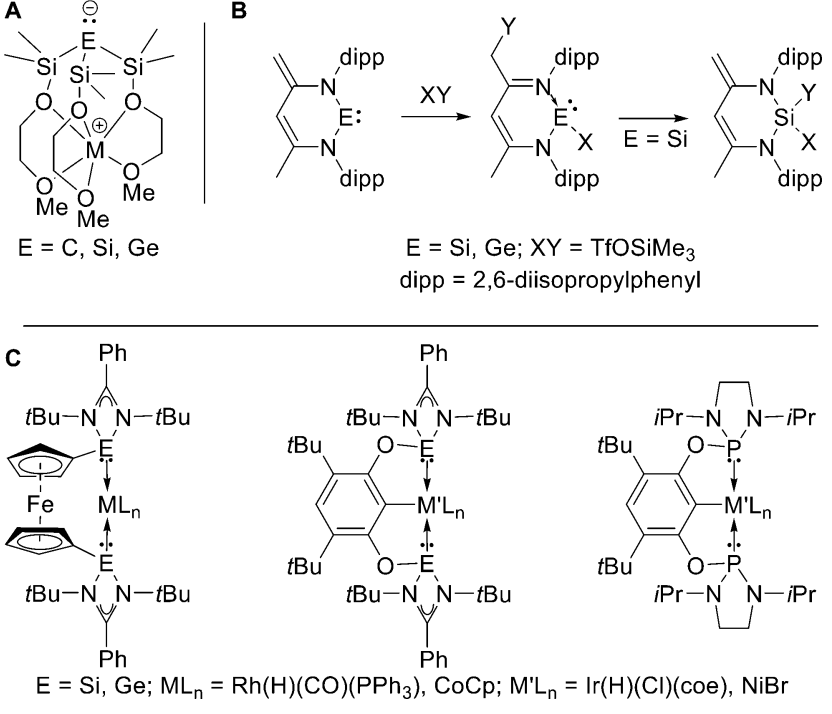

bridged disilylene ligand (Scheme 1, C) proved to be much more active than its germylene analogue. ${ }^{22}$ This difference was attributed to the enhanced $\sigma$-donor strength of the silylene. The same trend was observed in the cyclotrimerization reaction of phenylacetylene catalyzed by the analogous CoCp complex. ${ }^{6}$ The decreased reactivity of the germylene complex is in this case attributed to a stronger coordination of Ge to $\mathrm{Co}$, hampering the creation of an active site. Interestingly, in the $\mathrm{C}-\mathrm{H}$ borylation of arenes catalyzed by an iridium $\mathrm{SiCSi}$ pincer complex featuring two silylene donor moieties (Scheme $1, \mathrm{C})$, the yield was only slightly higher compared to the germylene (90\% and $80 \%)$, but significantly higher compared to the related phosphine complex $(64 \%) .{ }^{10}$ The increased reactivity of the $\mathrm{Si}$ and $\mathrm{Ge}$ complexes is thought to arise from stronger $\sigma$-donor properties compared to P. Complexes of these ligands with $\mathrm{NiBr}$ showed similar reactivity for the silylene and phosphine in a Sonogashira coupling. Interestingly, the germylene complex showed an increased yield from $40 \%$ to $53 \%$ compared to the silylene complex..$^{\text {a }}$

In recent work from our group, the synthesis and coordination chemistry of an unusual $\mathrm{Si}$ (II) anion supported by the tmim scaffold ( $\operatorname{tmimH}_{3}=\operatorname{tris}$ (3-methylindol-2-yl)methane) by substitution on a $\mathrm{Si}(\mathrm{II})$ precursor was reported. ${ }^{23}$ The introduction of electron-withdrawing groups to delocalize the negative charge and the tight cage structure are thought to enhance the stability of the anion by lowering the energy of the lone pair. To gain understanding on the influence of this cage design on ligand properties, the analogous germanide 1 (Chart 1) was investigated. All-nitrogen substituted germanides similar to $\mathbf{1}$ have received some attention, examples including triazidogermanide $\mathbf{A}$, bicyclo triamidogermanide $\mathbf{B}$, and the zwitterionic tripyrazolyl germanide $\mathbf{C}$ (Chart 1$).^{24-30}$ Their coordination chemistry is scarce, and structurally characterized complexes are limited to a tungsten(II) complex derived from structure A, a gold(I) complex derived from structure $\mathbf{B}$, and iron(II) complexes of a tetradentate triphosphinogermyl ligand. ${ }^{24-26}$ In the current work, the synthesis of compound 1 and its complexation to soft Lewis-acidic metal fragments
Chart 1. Naked Tri-nitrogen Substituted Germanides

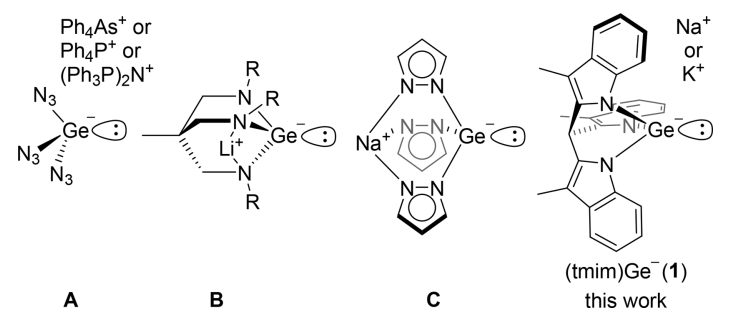

$\left(\mathrm{CuCl}, \mathrm{Cu}(\mathrm{NCMe})_{3}\right.$, and $\left.\mathrm{Fe}(\mathrm{CO})_{4}\right)$ is reported. In contrast to the silanide, coordination to the harder Lewis acid $\mathrm{FeCl}_{2}$ results in at most a weak interaction with a small association constant in solution. The properties of $\mathbf{1}$ as a ligand are compared with those of $(\mathrm{tmim}) \mathrm{Si}^{-}$as well as the neutral $\mathrm{P}$ (III) analogue previously reported by Barnard and Mason, ${ }^{31}$ showing that its donor ability is situated between those. Analysis of the $\mathrm{N}-\mathrm{E}-\mathrm{N}$ angles, $\mathrm{N}-\mathrm{E}$, and $\mathrm{E}-\mathrm{M}$ distances provides insight in the electronic nature of the ligands.

\section{RESULTS AND DISCUSSION}

The substituent (tmim) $\mathrm{H}_{3}$ was synthesized and deprotonated according to published procedures. ${ }^{23,32}$ Subsequently, the germanide 1 was synthesized by nucleophilic substitution of chloride for the tmim ${ }^{3-}$ trianion on $\mathrm{GeCl}_{2}$-dioxane (Scheme $2)$, which is a common approach to synthesize germanides. $^{24-29,33,34}$ The germanide was obtained either as its sodium salt $1-\mathrm{Na}$ or as its potassium salt $1-\mathrm{K}$. The synthesis of 1-Na requires an excess of $\mathrm{GeCl}_{2}$. dioxane to reach completion, which is tentatively attributed to formation of insoluble $\mathrm{NaGeCl}_{3}$. In contrast, a stoichiometric amount of $\mathrm{GeCl}_{2}$.

Scheme 2. Synthesis of 1-M by Nucleophilic Substitution of $\mathrm{Cl}$ for tmim in $\mathrm{GeCl}_{2} \cdot$ Dioxane and Synthesis of TransitionMetal Complexes 2-4

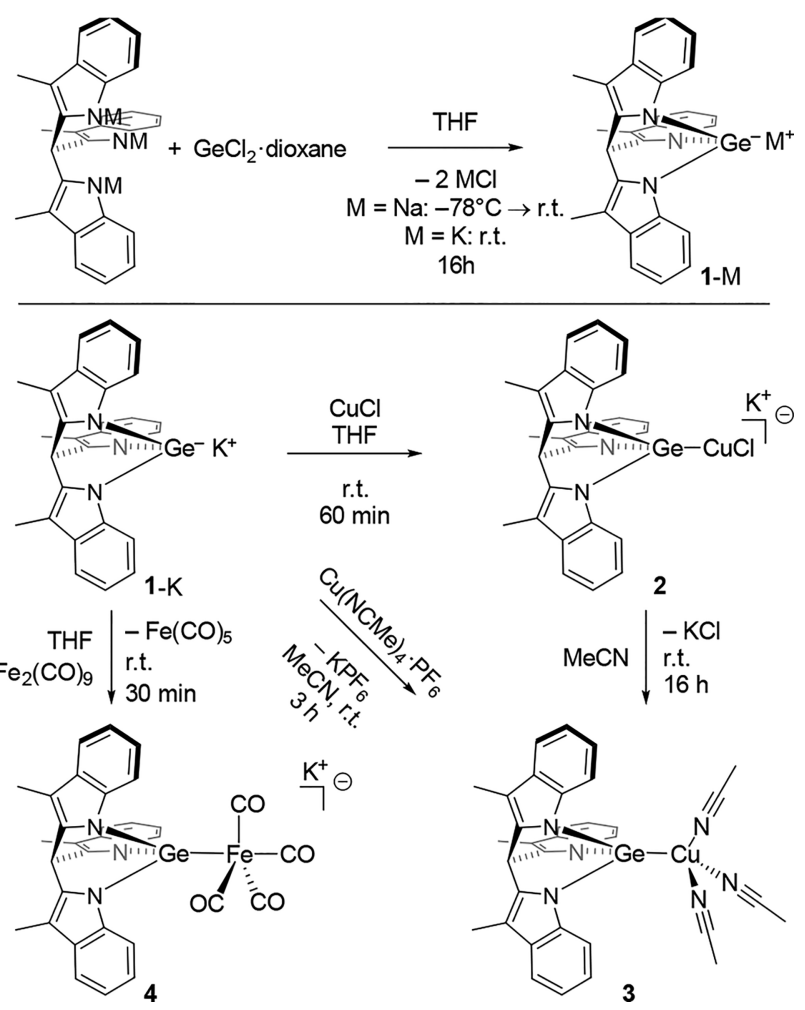


dioxane was sufficient for the synthesis of $1-\mathrm{K}$. Therefore, the potassium salt $1-\mathrm{K}$ was used for complexation studies.

A single set of ${ }^{1} \mathrm{H}$ resonances in the aromatic region indicates that 1 possesses three-fold symmetry, as expected for a bicyclo[2.2.2] octane topology. The presence of 1 was detected by ESI-MS as the molecular anion $\left(\mathrm{M}^{-}(1-\mathrm{K})=\right.$ measured: 474.1060 a.u., calcd: 474.1031 a.u.). Crystals of 1$\mathrm{Na}$ suitable for $\mathrm{X}$-ray diffraction were grown by storing a concentrated sample of $1-\mathrm{Na}$ in THF at $-35^{\circ} \mathrm{C}$ for 2 days. The molecular structure shows the presence of a free tricoordinate germanide with a solvated sodium counterion (Figure 1). The $\mathrm{N}-\mathrm{Ge}-\mathrm{N}$ angles provide a crude measure for

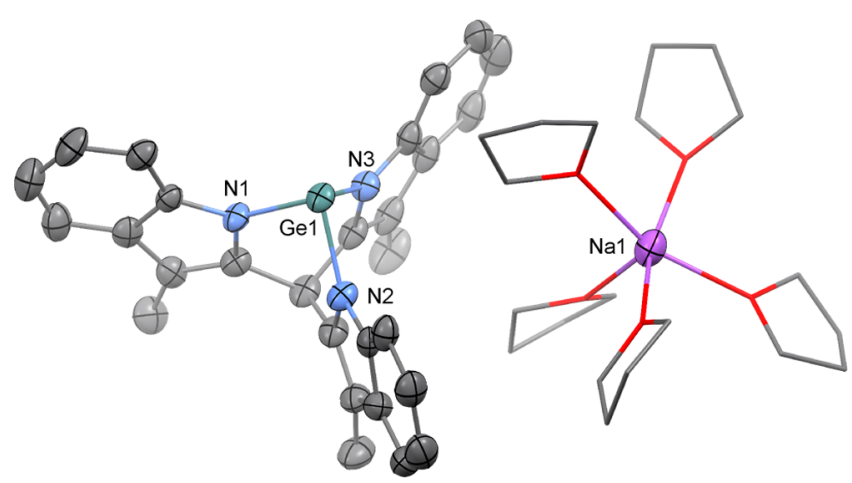

Figure 1. Molecular structure of 1-Na in the crystal. Ellipsoids are drawn at the $50 \%$ probability level. Only the major component of the disordered THF is shown. Hydrogen atoms are omitted for clarity. Selected bond distances $[\AA]$ and angles [deg]: N1-Ge1 1.956(4), N2-Ge1 1.969(4), N3-Ge1 1.970(4), N1-Ge1-N2 87.98(18), N2-Ge1-N3 88.02(18), N1-Ge1-N3 87.47(18).

the extent of hybridization of the Ge valence orbitals $(\mathrm{s}, \mathrm{p}){ }^{35}$ Ideally, the sum of angles is $270^{\circ}$ in nonhybridized and $328.5^{\circ}$ in $\mathrm{sp}^{3}$ hybridized systems. The sum of the $\mathrm{N}-\mathrm{Ge}-\mathrm{N}$ angles $\left(263.5(3)^{\circ}\right)$ suggests negligible hybridization of the Ge valence orbitals, with the lone pair located in the s-orbital. Angles close to $90^{\circ}$ are commonly found in germanides, also in the absence of a cage structure enforcing them, as for example in compound A (Chart 1). ${ }^{27,28,36-38}$ This is a consequence of the generally low propensity of heavier elements to undergo orbital hybridization, i.e., the inert pair effect. ${ }^{14-18}$

The coordination chemistry of the synthesized germanide was investigated with first-row transition-metal synthons (Scheme 2). Germanide $1-\mathrm{K}$ was complexed to 1 equiv of $\mathrm{CuCl}$ in $\mathrm{THF}$ at ambient temperature to form the chloro cuprate 2. A single set of ${ }^{1} \mathrm{H}$ resonances in the aromatic region shows retention of three-fold symmetry. In solution, the chloro cuprate exists as a monomer as was evidenced by the identical diffusion coefficients observed in DOSY NMR for $\mathbf{1}$ and $\mathbf{2}$ in $\mathrm{C}_{4} \mathrm{D}_{8} \mathrm{O}$. Crystals suitable for $\mathrm{X}$-ray diffraction were grown from a concentrated THF solution at $-35{ }^{\circ} \mathrm{C}$. In the solid state, complex $\mathbf{2}$ has two independent dimeric $\mathrm{Cu}$ complexes in the asymmetric unit which are both located on general positions without symmetry. Consequently, there are four independent germanide ligands. The dimers are characterized by $\mathrm{Cu}_{2} \mathrm{Cl}_{2}$ diamond cores, similar to the (tmim) Si chloro cuprate. ${ }^{23}$ Unlike the silicon analogue, the structure of 2 is slightly bent: the $\mathrm{Cl}-\mathrm{Cu}-\mathrm{Cl}$ planes form angles of $21.2(2)^{\circ}$ and $20.6(2)^{\circ}$ for the two independent dimers. The sum of the $\mathrm{N}-\mathrm{Ge}-\mathrm{N}$ angles in the four independent germanide ligands are 273.0(6), 272.7(6), 272.6(6), and $272.3(6)^{\circ}$. This suggests a slight rehybridization in the direction of $\mathrm{sp}^{3}$ compared to the free germanide 1 , for which the sum of the $\mathrm{N}-\mathrm{Ge}-\mathrm{N}$ angles is $263.5(3)^{\circ}$. Compound 2 constitutes only the second structurally characterized example of a germyl cuprate, next to bis(triphenylgermyl)copper as reported by Orlov et al. ${ }^{39}$ Diamond core dimeric structures $\left(\mathrm{Cu}_{2} \mathrm{X}_{2} ; \mathrm{X}=\mathrm{C}_{6} \mathrm{~F}_{5}, \mathrm{I}\right)$ related to 2 were previously observed for germylene complexes bearing nacnac- and aminotroponiminate ligands. ${ }^{40-42}$ This diamond core is generally planar; it is bent only in a $\mathrm{Cu}_{2} \mathrm{I}_{2}$ complex bearing a bidentate digermylene ligand, forcing the bent geometry. ${ }^{43}$ The $\mathrm{Ge}-\mathrm{Cu}$ bond lengths of $2.2557(17)-$ 2.2611(17) $\AA$ in 2 are remarkably short, shorter distances being found only in germylene complexes of copper 1,3diketimines. $^{44}$

The chloride in anionic cuprate 2 can be replaced by acetonitrile to form a neutral copper germanide, similarly to what is observed for the silicon analogue. ${ }^{23}$ A saturated solution of 2 in acetonitrile produces crystals within $16 \mathrm{~h}$ (Figure 2). The solid-state structure of 3 shows a monomeric, tris-acetonitrile complex. This complex is one of a few neutral monodentate germyl copper complexes. ${ }^{45-48}$ The $\mathrm{Ge}-\mathrm{Cu}$ distance in 3 (Ge1-Cu1 2.2921(3) $\AA$ ) is the shortest observed for such complexes. ${ }^{45,46}$ To determine whether the chlorocuprate dissociates in acetonitrile and THF solution, an authentic sample of neutral 3 was synthesized by complexation of $1-\mathrm{K}$ to $\mathrm{Cu}(\mathrm{MeCN})_{4} \cdot \mathrm{PF}_{6}$. The ${ }^{1} \mathrm{H} \mathrm{NMR}$ spectrum of the resulting complex is identical to that of 2 in $\mathrm{CD}_{3} \mathrm{CN}$, whereas a significant difference can be seen in the chemical shift of the indole- $\mathrm{H} 7$ between both samples in THF (7.62, $7.94 \mathrm{ppm}$ for 3 and 2, respectively). This suggests that complex 2 exists as a molecular chlorocuprate in THF but dissociates to the neutral complex 3 in acetonitrile.

The synthesis of an $\mathrm{Fe}(\mathrm{CO})_{4}$ derivative of compound $\mathbf{1}$ is of interest as a way to investigate its electronic properties as a ligand. Reaction of $1-\mathrm{K}$ with $\mathrm{Fe}_{2}(\mathrm{CO})_{9}$ in $\mathrm{THF}$ at room temperature afforded very cleanly the $\mathrm{Fe}(\mathrm{CO})_{4}$ complex 4 (Figure 2) with loss of $\mathrm{Fe}(\mathrm{CO})_{5}$. Retention of the three-fold symmetry is indicated by a single set of ${ }^{1} \mathrm{H}$ NMR resonances in the aromatic region. Crystals suitable for X-ray diffraction were grown by diffusion of hexane into a concentrated THF solution of 4 . The structure is very similar to that of the neutral phosphine analogue $(\mathrm{tmim}) \mathrm{PFe}(\mathrm{CO})_{4}$ reported by Barnard and Mason. ${ }^{49}$ The distinct axial and equatorial $\mathrm{CO}$ resonances of 4 in ${ }^{13} \mathrm{C}$ NMR were observed in a $1: 3$ ratio at $-40{ }^{\circ} \mathrm{C}(\delta=$ $222.57,212.16 \mathrm{ppm})$ and 1 coalesced resonance at $70^{\circ} \mathrm{C}(\delta=$ $215.53 \mathrm{ppm})$. One broad resonance at room temperature $(\delta=$ $215.15 \mathrm{ppm}$, fwhm $=125 \mathrm{~Hz}$ ) suggests that this is above the coalescence temperature. In (tmim) $\mathrm{PFe}(\mathrm{CO})_{4}$, similar fluxional behavior was ascribed to hindered axial-equatorial exchange of the carbonyl ligands caused by steric repulsion of the indole rings on the carbonyls in the square pyramidal intermediate of plausible Berry pseudorotation ${ }^{50}$ as well as turnstile rotation. ${ }^{49}$ For the phosphine complex, the coalescence temperature is estimated to be $97{ }^{\circ} \mathrm{C}$, albeit not observed. ${ }^{31}$ The lower coalescence temperature for the germanium analogue suggests a lower energy barrier for the carbonyl exchange, which can be ascribed to the longer $\mathrm{Ge}-\mathrm{Fe}$ (2.2978(16) A) bond with respect to the $\mathrm{P}-\mathrm{Fe}$ bond (2.1539(5) $\AA)$, reducing steric congestion around the iron center.

Whereas copper chloride and iron carbonyl give well-defined complexes with germanide 1 , it binds only weakly to $\mathrm{FeCl}_{2}$ (Scheme 3). In the ${ }^{1} \mathrm{H}$ NMR of an equimolar solution of $1-\mathrm{K}$ 

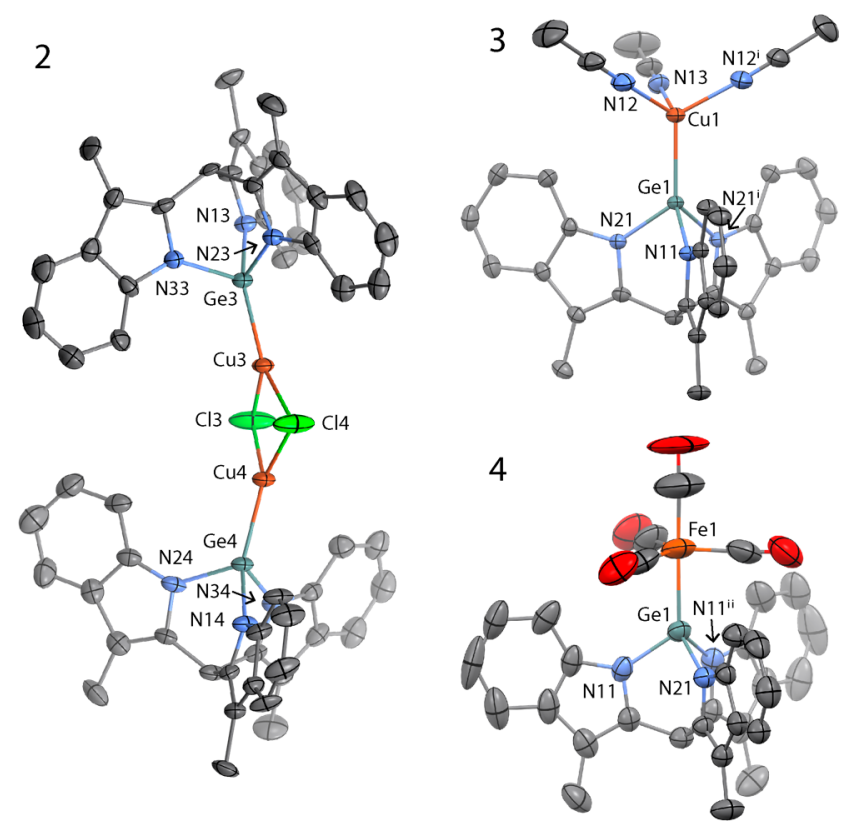

Figure 2. Molecular structure of the dianion of 2, neutral 3, and the anion of 4 in the crystal. Ellipsoids are drawn at the 50\% probability level. Hydrogen atoms, THF solvated potassium cations, and cocrystallized, non-coordinated $\mathrm{MeCN}$ are omitted for clarity. Atom labels marked with ${ }^{\mathrm{i}}$ or ${ }^{\mathrm{ii}}$ arise from mirror symmetry. The asymmetric unit of 2 contains two independent molecules of which one is shown. Selected bond distances $[\AA]$ and angles [deg]: 2: Molecule 1: Ge1Cu1 2.2591(17), Ge2-Cu2 2.2557(17), Ge1-N11 1.899(8), Ge1N21 1.898(8), Ge1-N31 1.906(9), Ge2-N12 1.911(8), Ge2-N22 1.906(9), Ge2-N32 1.918(8), N11-Ge1-N21 90.3(3), N21-Ge1N31 91.4(4), N31-Ge1-N11 91.3(3), N12-Ge2-N22 90.6(4), $\mathrm{N} 22-\mathrm{Ge} 2-\mathrm{N} 32$ 91.3(4), N32-Ge2-N12 90.8(3), angle between planes $\mathrm{Cl} 1-\mathrm{Cu} 1-\mathrm{Cl} 2$ and $\mathrm{Cl} 1-\mathrm{Cu} 2-\mathrm{Cl} 2$ : 21.2(2). Molecule 2: Ge3-Cu3 2.2611(17), Ge4-Cu4 2.2604(16), Ge3-N13 1.907(8), Ge3-N23 1.902(9), Ge3-N33 1.901(8), Ge4-N14 1.909(8), Ge4N24 1.917(9), Ge4-N34 1.898(9), N13-Ge3-N23 90.6(4), N23Ge3-N33 91.4(4), N33-Ge3-N13 90.6(3), N14-Ge4-N24 90.3(3), N24-Ge4-N34 91.9(4), N34-Ge4-N14 90.1(4), angle between planes $\mathrm{Cl} 3-\mathrm{Cu} 3-\mathrm{Cl} 4$ and $\mathrm{Cl} 3-\mathrm{Cu} 4-\mathrm{Cl} 4: 20.6(2) ; 3: \mathrm{Ge} 1-$ Cu1 2.2921(3), Ge1-N11 1.9110(16), Ge1-N21 1.9162(11), N11Ge1-N21 90.19(5), N21-Ge1-N21 $1^{\mathrm{i}} 88.69(7)$ (symmetry code $i: x$, $1-y, z) ; 4:$ Ge1-Fe1 2.2978(16), Ge1-N11 1.890(5), Ge1-N21 1.902(6), N11-Ge1-N21 92.57(18), N11-Ge1-N11 ${ }^{\mathrm{ii}}$ 92.4(3) (symmetry code $i i: 1-x, y, z$ ).

Scheme 3. Coordination of the Silanide and Germanide Ligands to Iron Dichloride ${ }^{a}$

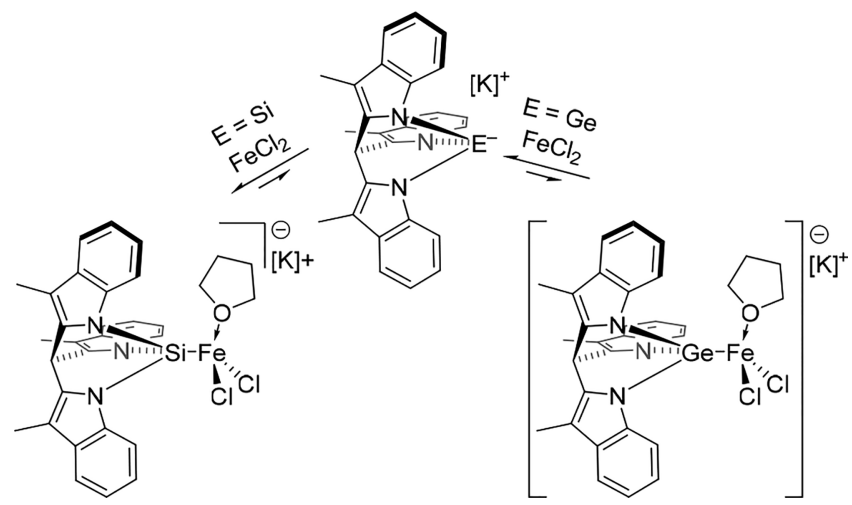

${ }^{a}[\mathrm{~K}]^{+}=\mathrm{K}(18 \text {-crown-6) })^{+}$for $\mathrm{E}=\mathrm{Si}$ and $\mathrm{K}^{+}$for $\mathrm{E}=\mathrm{Ge}$. and $\mathrm{FeCl}_{2}$ in $\mathrm{THF}$, the indole-H7 peak broadens (fwhm, from 2.8 to $40 \mathrm{~Hz}$ ) and shifts $0.50 \mathrm{ppm}$ to low field (Figure 3).

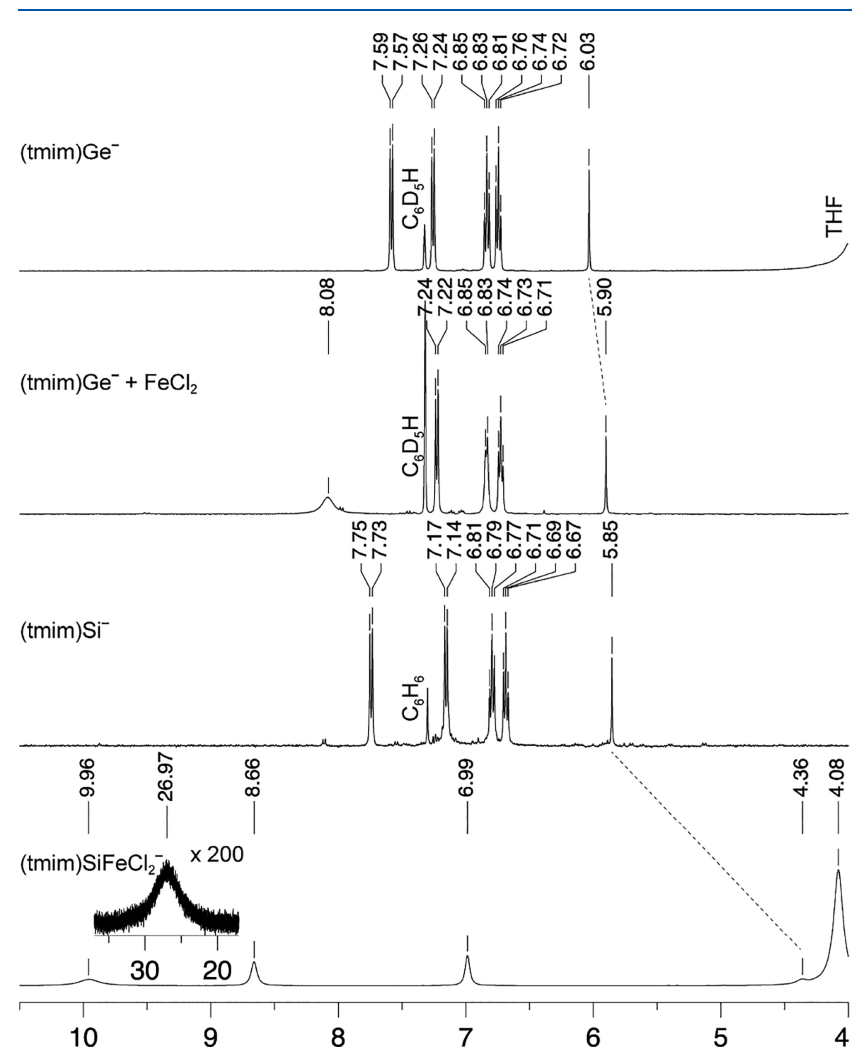

Figure 3. ${ }^{1} \mathrm{H}$ NMR spectra of $(\mathrm{tmim}) \mathrm{E}^{-}$compounds $(\mathrm{E}=\mathrm{Ge}, \mathrm{Si}$, $\mathrm{SiFeCl}_{2}$ ) and an equimolar mixture of $1-\mathrm{K}$ and $\mathrm{FeCl}_{2}$ in $\mathrm{THF}-\mathrm{H}_{8}+$ $\mathrm{C}_{6} \mathrm{D}_{6}(\mathrm{Ge})$ or THF- $d_{8}(\mathrm{Si})$.

Concomitantly, the $\mathrm{R}_{3} \mathrm{CH}$ signal shifts $0.13 \mathrm{ppm}$ to high field. This is in contrast with (tmim) $\mathrm{Si}^{-}$, which binds to $\mathrm{FeCl}_{2}$ to form (tmim) $\mathrm{SiFeCl}_{2} \cdot \mathrm{THF}$, causing a low-field shift of $20 \mathrm{ppm}$ for the indole- $\mathrm{H} 7$ and a high-field shift of $1.5 \mathrm{ppm}$ for the $\mathrm{R}_{3} \mathrm{CH}$ signal. ${ }^{23}$ The weaker affinity of $\mathbf{1}$ for $\mathrm{FeCl}_{2}$ with respect to (tmim) $\mathrm{Si}^{-}$can be understood in terms of Hard and Soft Acids and Bases (HSAB), the germanide being a softer Lewis base than the silanide.

The series of Ge compounds described herein provide a rare opportunity to compare side by side the properties of isostructural ligands featuring three different central elements, namely, $\mathrm{P}(\mathrm{III}),{ }^{31,49} \mathrm{Si}(\mathrm{II}),{ }^{23}$ and $\mathrm{Ge}(\mathrm{II})$. Key geometrical and spectroscopic parameters are collected in Table 1 . In the solid state, the anions (tmim) $\mathrm{Ge}^{-}$and (tmim) $\mathrm{Si}^{-}$possess rather acute $\mathrm{N}-\mathrm{E}-\mathrm{N}$ angles $\left(\sum(\mathrm{N}-\mathrm{Si}-\mathrm{N})=272.58(9)^{\circ}, \sum(\mathrm{N}-\right.$ $\left.\mathrm{Ge}-\mathrm{N})=263.5(3)^{\circ}\right)$, with respect to the phosphine analogue $\left(\sum(\mathrm{N}-\mathrm{P}-\mathrm{N})=285.30(12)^{\circ}\right.$, Table 1$) \cdot{ }^{31,49}$ The more acute angles in (tmim) $\mathrm{Ge}^{-}$compared to (tmim) $\mathrm{Si}^{-}$likely arise from the larger atomic radius of germanium, because the throughspace $\mathrm{N} \cdots \mathrm{CH} \cdots \mathrm{N}$ angles are larger in (tmim) $\mathrm{Ge}^{-}$, indicating that the tmim scaffold needs to open up to accommodate the larger $\mathrm{Ge}^{-}$anion. This is also reflected in the $\mathrm{N}-\mathrm{E}$ distances being larger in (tmim) $\mathrm{Ge}^{-}$, but does not appear to result in substantial cage strain. The strain energy estimated computationally for (tmim) $\mathrm{Ge}^{-}$according to the homodesmotic reaction depicted in Scheme 4 is very low $(\Delta H=-1.0 \mathrm{kcal} /$ $\mathrm{mol})$, similarly to those calculated for $(\mathrm{tmim}) \mathrm{Si}^{-}(-1.6 \mathrm{kcal} /$ $\mathrm{mol})$ and (tmim)P (1.2 kcal/mol; Supporting Information, Table S2). ${ }^{23}$ The difference in N-E-N angles between $\mathrm{Si}$ and 
Table 1. Sum of Angles, Distances, and $\tilde{\nu}(\mathrm{CO})$ in tmimE Compounds $\left(\mathrm{E}=\mathrm{P}, \mathrm{Si}^{-}, \mathrm{Ge}^{-}\right)$and Their Complexes

\begin{tabular}{|c|c|c|c|}
\hline $\mathrm{E}=$ & $P$ & $\mathrm{Si}^{-}$ & $\mathrm{Ge}^{-}$ \\
\hline \multicolumn{4}{|l|}{ tmimE } \\
\hline$\sum \mathrm{N}-\mathrm{E}-\mathrm{N} / \mathrm{deg}$ & $285.30(12)$ & $272.58(9)$ & $263.5(3)$ \\
\hline$\langle\mathrm{N}-\mathrm{E}\rangle / \AA$ & $1.7084(8)$ & $1.8416(6)$ & $1.965(2)$ \\
\hline$\langle\mathrm{N} \cdots \mathrm{CH} \cdots \mathrm{N}\rangle / \mathrm{deg}$ & 62.3 & 64.7 & $67.40(12)$ \\
\hline \multicolumn{4}{|l|}{$[(\operatorname{tmimE}) \mathrm{Cu}(\mu-\mathrm{Cl})]_{2}^{2-}$} \\
\hline $\mathrm{Cu}-\mathrm{E} / \AA$ & & $2.1906(10)$ & $2.2557(17)-2.2611(17)^{b}$ \\
\hline$\sum \mathrm{N}-\mathrm{E}-\mathrm{N} / \mathrm{deg}$ & & $280.8(2)$ & $272.3(3)-273.0(6)^{b}$ \\
\hline$\overline{\langle N}-\mathrm{E}\rangle / \AA$ & & $1.8010(17)$ & $1.901(5)-1.912(5)^{b}$ \\
\hline \multicolumn{4}{|l|}{$(\operatorname{tmimE}) \mathrm{Cu}(\mathrm{NCMe})_{3}$} \\
\hline $\mathrm{Cu}-\mathrm{E} / \AA$ & & $2.2106(8)$ & $2.2921(3)$ \\
\hline$\sum \mathrm{N}-\mathrm{E}-\mathrm{N} / \mathrm{deg}$ & & $278.73(12)$ & $269.07(12)$ \\
\hline$\langle\mathrm{N}-\mathrm{E}\rangle / \AA$ & & $1.8063(10)$ & $1.9145(7)$ \\
\hline \multicolumn{4}{|l|}{$(\operatorname{tmimE}) \mathrm{Fe}(\mathrm{CO})_{4}$} \\
\hline $\mathrm{Fe}-\mathrm{E} / \AA ̊$ & $2.1539(5)$ & & $2.2978(16)$ \\
\hline$\sum \mathrm{N}-\mathrm{E}-\mathrm{N} / \mathrm{deg}$ & $292.56(12)$ & & $277.5(4)$ \\
\hline$\langle\mathrm{N}-\mathrm{E}\rangle / \AA$ & $1.7085(8)$ & & $1.894(3)$ \\
\hline$\tilde{\nu}(\mathrm{CO}) / \mathrm{cm}^{-1} \exp$ & 207620061977 & $2029^{a} 1920$ & 203719541933 \\
\hline$\tilde{\nu}(\mathrm{CO}) / \mathrm{cm}^{-1} \mathrm{calcd}$ & 207420121990 & 202619561939 & 203219611948 \\
\hline
\end{tabular}

Scheme 4. Homodesmotic Reaction Used for Strain Calculations ${ }^{23}$

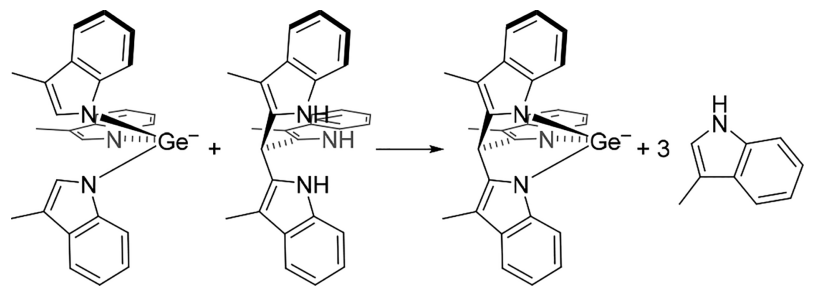

$\mathrm{P}$ is likely a combined effect of the slightly larger $\mathrm{P}$ radius and the absence of a negative charge on phosphorus, i.e., less repulsion for the anionic indole moieties.

The solid-state structures of the complexes presented herein correlate with changes in orbital hybridization at the central atom. Upon complexation, the $\mathrm{N}-\mathrm{E}-\mathrm{N}$ angles increase in all ligands, which can be explained by an increasing p-character of the lone pair upon binding to a Lewis acid and a consequent decrease in the p-character of the $\mathrm{E}-\mathrm{N}$ bonding orbitals. This is in agreement with Bent's rule: increased electronegativity of a substituent (from a lone pair to a metal fragment) results in increased p-character of the bonding orbitals. ${ }^{35}$ The E-N distances decrease upon complexation for both (tmim)Si and 1 to $\mathrm{CuCl}$ and $\mathrm{Cu}(\mathrm{MeCN})_{3}$, but the $\mathrm{E}-\mathrm{N}$ distances in (tmim) $\mathrm{P}$ remain unchanged within the error bounds upon complexation to $\mathrm{Fe}(\mathrm{CO})_{4}$. This difference can be interpreted as a consequence of the stronger electron-donor character of the anionic ligands as compared with (tmim) $\mathrm{P}$, which results in a higher degree of charge transfer upon complexation, causing a shortening of the $\mathrm{N}-\mathrm{E}$ bonds as the electron density at the central element is depleted.

In the cuprates derived from (tmim) $\mathrm{Ge}^{-}$and $(\mathrm{tmim}) \mathrm{Si}^{-}$, the $\mathrm{E}-\mathrm{Cu}$ distances are very short and congruent $(\Delta d(\mathrm{E}-\mathrm{Cu})=$ $0.0686(13) \AA)$ if one takes into account the difference in covalent radii between $\mathrm{Si}$ and $\mathrm{Ge}(0.09(4) \AA) .{ }^{12}$ The metal fragment in the acetonitrile complexes is somewhat less electron-withdrawing as is reflected in tightening of the $\mathrm{N}-$ $\mathrm{E}-\mathrm{N}$ angles and a slight increase in $\mathrm{E}-\mathrm{N}$ distance from $\mathrm{LCuCl}^{-}$to $\mathrm{LCu}(\mathrm{NCMe})_{3}$, correlating with slightly longer $\mathrm{Cu}-$
E bonds. This can be taken to indicate that the increase in coordination number in the acetonitrile complex outweighs the loss of the more electron-rich, anionic chloride ligand.

For comparison with 4, complexation of (tmim) $\mathrm{Si}^{-}$to $\mathrm{Fe}(\mathrm{CO})_{4}$ was investigated. It affords a mixture of two major components of which one is tentatively assigned to [(tmim)$\left.\mathrm{SiFe}(\mathrm{CO})_{4}\right]^{-}$on the basis of ESI-MS and IR (in combination with DFT-calculated $\tilde{\nu}(\mathrm{CO})$, Table 1$)$. Isolation of the silyl iron complex was unsuccessful. The vibrational frequency of the carbonyls in (tmim)EFe $(\mathrm{CO})_{4}\left(\mathrm{E}=\mathrm{Si}^{-}, \mathrm{Ge}^{-}, \mathrm{P}\right.$; Table 1) indicates that the silanide is the strongest electron donor, the germanide is somewhat weaker, and the phosphine is a significantly weaker donor.

\section{CONCLUSIONS}

The free germanide $(\mathrm{tmim}) \mathrm{Ge}^{-}\left(\mathbf{1},(\mathrm{tmim}) \mathrm{H}_{3}=\right.$ tris (3methylindol-2-yl)methane) was synthesized through nucleophilic substitution on $\mathrm{GeCl}_{2}$.dioxane by the trianion tmim ${ }^{3-}$. Germanide 1 was shown to coordinate to $\mathrm{Cu}(\mathrm{I})$ and $\mathrm{Fe}(0)$ fragments, affording the chloro cuprate $[(\mathrm{tmim}) \mathrm{GeCuCl}]^{-}$and the iron carbonyl complex $\left[(\mathrm{tmim}) \mathrm{GeFe}(\mathrm{CO})_{4}\right]^{-}$. The chloro cuprate was shown to dissociate in acetonitrile to give the neutral acetonitrile solvated complex (tmim) $\mathrm{GeCu}(\mathrm{NCMe})_{3}$. Contrasting with the reactivity of the analogous silanide, coordination of $\mathbf{1}$ to $\mathrm{FeCl}_{2}$ results in at most a weak interaction. With the existence of the analogous (tmim) P and (tmim) $\mathrm{Si}^{-}$, and complexes thereof, a rare opportunity arose of comparing the properties of isostructural ligands featuring different central elements, namely, P(III), Si(II), and $\mathrm{Ge}(\mathrm{II})$. The relative electron donor strength was interrogated from the observed $\tilde{\nu}(\mathrm{CO})$ in IR spectroscopy, showing that the donor strength follows the trend $P<\mathrm{Ge}<\mathrm{Si}$. Analysis of the $\mathrm{N}-\mathrm{E}-\mathrm{N}$ angles, $\mathrm{N}-\mathrm{E}$, and $\mathrm{E}-\mathrm{M}$ distances provides insight in the electronic nature of the ligands, suggesting increased hybridization of the Ge s- and p-orbitals upon complexation to a metal fragment. The findings presented here contribute to the understanding of low-valent heavier group 14 ligands and their complexes and may provide important insights necessary for further development of this promising class of ligands. 


\section{EXPERIMENTAL SECTION}

All reactions involving air-sensitive compounds were conducted under a $\mathrm{N}_{2}$ atmosphere by using standard glovebox or Schlenk techniques. Acetonitrile and $n$-hexane were dried with an MBRAUN MB SPS-79 system; THF was distilled from benzophenone/ $\mathrm{Na}$. All solvents were degassed by bubbling with $\mathrm{N}_{2}$ for $30 \mathrm{~min}$, and stored over molecular sieves in a glovebox. Deuterated acetonitrile and THF were degassed by four freeze-pump-thaw cycles and stored over molecular sieves in a glovebox. Skatole, $\mathrm{NaH}$ (60 wt \% in mineral oil), $\mathrm{KH}$ (30 wt \% in mineral oil), and $\mathrm{FeCl}_{2}$ were purchased from Sigma-Aldrich. Triethyl orthoformate, $\mathrm{Fe}_{2}(\mathrm{CO})_{9}$, and $\mathrm{CuCl}$ were purchased from Acros. $\mathrm{GeCl}_{2}$-dioxane was purchased from ABCR. All commercially obtained chemicals were used as received, except for $\mathrm{CuCl}$. From $\mathrm{CuCl}$, copper oxides and hydroxides were removed with hydrochloric acid as described in the literature, and the resulting solid was azeotropically dried with acetonitrile until $\tilde{\nu}(\mathrm{C} \equiv \mathrm{N})$ in the IR spectrum disappeared. ${ }^{51}$ All NMR measurements were performed on a Varian VNMRS400 or Varian MRF400 spectrometer; shifts are reported relative to TMS with the residual solvent signal as internal standard. ${ }^{52}$ All NMR experiments involving air-sensitive compounds were conducted in J-Young NMR tubes under a $\mathrm{N}_{2}$ atmosphere. Salts of solvated sodium or potassium cations generally yielded unreliable elemental analysis data due to partial desolvation. Their purity was established by NMR spectroscopy. In particular, the THF content determination for purity purposes was done by NMR; the acquisition time was chosen so that the full FID was recorded. Additionally, the relaxation time was set to 7 times the longest $T_{1}$, determined by an individual $\mathrm{T}_{1}$ measurement. IR spectra were recorded on a PerkinElmer Spectrum Two FT-IR spectrometer. ESI-MS measurements were performed on a Waters LCT Premier XE KE317 spectrometer; the Waters software was used for simulations. Elemental analysis was conducted by the Mikroanalytisches Laboratorium Kolbe $(3,4)$ or Medac Ltd. (2). The experimental methods and parameters of the X-ray crystal structure determinations are detailed in the Supporting Information. The compounds $($ tmim $) \mathrm{H}_{3},{ }^{32}$ (tmim) $\mathrm{Na}_{3},{ }^{23}($ tmim $) \mathrm{K}_{3},{ }^{23}$ and $(\mathrm{tmim}) \mathrm{Si}^{-23}$ were prepared according to reported procedures.

Computational Methods. Calculations were performed using Gaussian 09, Revision D.01. ${ }^{53}$ The absence of negative eigenvalues was confirmed for all structures. All structures were optimized using the TPSS functional with the TZVP basis set.

Syntheses. Synthesis of $\mathrm{Na}[(\mathrm{tmim}) \mathrm{Ge}]$ (1-Na). Solutions of (tmim) $\mathrm{Na}_{3}$ (501 mg, $27 \mathrm{wt} \%$ THF, $\left.0.78 \mathrm{mmol}\right)$ in THF $(10 \mathrm{~mL})$ and $\mathrm{GeCl}_{2}$.dioxane $(337 \mathrm{mg}, 1.46 \mathrm{mmol})$ in THF $(6 \mathrm{~mL})$ were cooled to $-78{ }^{\circ} \mathrm{C}$. The $\mathrm{GeCl}_{2} \cdot$ dioxane solution was added to the stirred tmim solution, resulting in a suspension. This was allowed to warm to r.t. over $16 \mathrm{~h}$. Filtration and removal of the solvent, followed by recrystallization from THF at $-35^{\circ} \mathrm{C}$ and drying in vacuo, afforded a yellow powder (190 mg, $34 \mathrm{wt} \% \mathrm{THF}, 0.405 \mathrm{mmol}, 32 \%) .{ }^{1} \mathrm{H}$ NMR $\left(400 \mathrm{MHz}, \mathrm{CD}_{3} \mathrm{CN}, 25^{\circ} \mathrm{C}\right) \delta=7.56\left(\mathrm{dt},{ }^{3} \mathrm{~J}(\mathrm{H}, \mathrm{H})=8.3 \mathrm{~Hz},{ }^{4} \mathrm{~J}(\mathrm{H}, \mathrm{H})\right.$ $=0.8 \mathrm{~Hz},{ }^{5} \mathrm{~J}(\mathrm{H}, \mathrm{H})=0.8 \mathrm{~Hz}, 3 \mathrm{H}$, Indole- $\left.\underline{\mathrm{H}} 7\right), 7.32\left(\mathrm{dt},{ }^{3} \mathrm{~J}(\mathrm{H}, \mathrm{H})=7.8\right.$ $\mathrm{Hz},{ }^{4} \mathrm{~J}(\mathrm{H}, \mathrm{H})=1.1 \mathrm{~Hz},{ }^{5} \mathrm{~J}(\mathrm{H}, \mathrm{H})=1.1 \mathrm{~Hz}, 3 \mathrm{H}$, Indole- $\left.\underline{\mathrm{H}} 4\right), 6.92(\mathrm{ddd}$, ${ }^{3} J(\mathrm{H}, \mathrm{H})=8.1 \mathrm{~Hz},{ }^{3} J(\mathrm{H}, \mathrm{H})=7.0 \mathrm{~Hz},{ }^{4} J(\mathrm{H}, \mathrm{H})=1.3 \mathrm{~Hz}, 3 \mathrm{H}$, IndoleH6), $6.83\left(\mathrm{ddd},{ }^{3} \mathrm{~J}(\mathrm{H}, \mathrm{H})=7.9 \mathrm{~Hz},{ }^{3} \mathrm{~J}(\mathrm{H}, \mathrm{H})=7.0 \mathrm{~Hz},{ }^{4} \mathrm{~J}(\mathrm{H}, \mathrm{H})=1.1\right.$ $\mathrm{Hz}, 3 \mathrm{H}$, Indole- $\underline{\mathrm{H}} 5), 6.01$ (s, $\left.1 \mathrm{H}, \mathrm{R}_{3} \mathrm{C} \underline{\mathrm{H}}\right), 2.43 \mathrm{ppm}\left(\mathrm{s}, 9 \mathrm{H}, \mathrm{C}_{3}\right) .{ }^{13} \mathrm{C}$ NMR (101 MHz, CD $\left.{ }_{3} \mathrm{CN}, 25{ }^{\circ} \mathrm{C}\right) \delta=141.9\left(2 \mathrm{x}{ }^{\mathrm{Ar}} \mathrm{q} \underline{\mathrm{C}}\right), 131.2\left({ }^{\mathrm{Ar}} \mathrm{q} \underline{\mathrm{C}}\right)$, $119.9\left({ }^{\mathrm{Ar}} \underline{\mathrm{C}} \mathrm{H}\right), 118.6\left({ }^{\mathrm{Ar}} \mathrm{CH}\right), 117.7\left({ }^{\mathrm{Ar}} \mathrm{CH}\right), 112.2\left({ }^{\mathrm{Ar}} \mathrm{CH}\right), 103.4$ $\left({ }^{\mathrm{Ar}} \mathrm{qC}\right), 34.2\left(\mathrm{R}_{3} \mathrm{CH}\right), 8.9 \mathrm{ppm}\left(\underline{\mathrm{CH}}_{3}\right)$. Satisfactory elemental analysis could not be obtained, likely due to THF solvation.

Synthesis of (tmim) GeK (1-K). A solution of $\mathrm{GeCl}_{2}$-dioxane (203 $\mathrm{mg}, 0.875 \mathrm{mmol})$ in THF $(6 \mathrm{~mL})$ was added over $20 \mathrm{~min}$ at room temperature to an orange, green luminescent solution of $(\mathrm{tmim}) \mathrm{K}_{3}$ ( $500 \mathrm{mg}, 10 \mathrm{wt} \% \mathrm{THF}, 0.869 \mathrm{mmol}$ ) in THF $(15 \mathrm{~mL})$ and stirred for $16 \mathrm{~h}$. The resulting yellow suspension was diluted to $40 \mathrm{~mL}$ with THF and centrifuged for $10 \mathrm{~min}$ at $2000 \mathrm{rpm}$. The decanted supernatant was concentrated to $6 \mathrm{~mL}$, during which precipitation occurred. Decanting and washing with THF $(4 \times 0.5 \mathrm{~mL})$ yielded a white microcrystalline powder $(297 \mathrm{mg})$. Repeated storing of the combined THF fractions at $-35{ }^{\circ} \mathrm{C}$ for $16 \mathrm{~h}$, decanting, and washing with cold
THF yielded two more crops $\left(m_{\text {total }}=506 \mathrm{mg}, 37 \mathrm{wt} \% \mathrm{THF}, 0.62\right.$ mmol, $71 \%) .{ }^{1} \mathrm{H}$ NMR $\left(400 \mathrm{MHz}, \mathrm{CD}_{3} \mathrm{CN}, 25{ }^{\circ} \mathrm{C}\right) \delta=7.58(\mathrm{dt}$, ${ }^{3} J(\mathrm{H}, \mathrm{H})=8.1 \mathrm{~Hz},{ }^{4} \mathrm{~J}(\mathrm{H}, \mathrm{H})=0.9 \mathrm{~Hz},{ }^{5} \mathrm{~J}(\mathrm{H}, \mathrm{H})=0.9 \mathrm{~Hz}, 3 \mathrm{H}$, Indole$\underline{\mathrm{H}} 7), 7.34\left(\mathrm{dt},{ }^{3} J(\mathrm{H}, \mathrm{H})=7.8 \mathrm{~Hz},{ }^{4} \mathrm{~J}(\mathrm{H}, \mathrm{H})=1.0 \mathrm{~Hz},{ }^{5} \mathrm{~J}(\mathrm{H}, \mathrm{H})=1.0\right.$ $\mathrm{Hz}, 3 \mathrm{H}$, Indole- $\mathrm{H} 4), 6.94\left(\mathrm{ddd},{ }^{3} J(\mathrm{H}, \mathrm{H})=8.1 \mathrm{~Hz},{ }^{3} J(\mathrm{H}, \mathrm{H})=6.9 \mathrm{~Hz}\right.$, ${ }^{4} J(\mathrm{H}, \mathrm{H})=1.3 \mathrm{~Hz}, 3 \mathrm{H}$, Indole- $\left.\underline{\mathrm{H}} 6\right), 6.85\left(\mathrm{ddd},{ }^{3} J(\mathrm{H}, \mathrm{H})=7.9 \mathrm{~Hz}\right.$, ${ }^{3} \mathrm{~J}(\mathrm{H}, \mathrm{H})=7.0 \mathrm{~Hz},{ }^{4} \mathrm{~J}(\mathrm{H}, \mathrm{H})=1.1 \mathrm{~Hz}, 3 \mathrm{H}$, Indole- $\left.\underline{\mathrm{H}} 5\right), 6.03(\mathrm{~s}, 1 \mathrm{H}$, $\left.\mathrm{R}_{3} \mathrm{C} \underline{\mathrm{H}}\right), 2.46 \mathrm{ppm}\left(\mathrm{s}, 9 \mathrm{H}, \mathrm{CH}_{3}\right) .{ }^{1} \mathrm{H}$ NMR $\left(400 \mathrm{MHz}, \mathrm{C}_{4} \mathrm{H}_{8} \mathrm{O}+\right.$ $\left.\mathrm{C}_{6} \mathrm{D}_{6}, 25^{\circ} \mathrm{C}\right) \delta=7.54\left(\mathrm{~d},{ }^{3} J(\mathrm{H}, \mathrm{H})=8.0 \mathrm{~Hz}, 3 \mathrm{H}\right.$, Indole- $\left.\underline{\mathrm{H}} 7\right), 7.21(\mathrm{~d}$, ${ }^{3} J(\mathrm{H}, \mathrm{H})=7.7 \mathrm{~Hz}, 3 \mathrm{H}$, Indole- $\left.\underline{\mathrm{H}} 4\right), 6.79\left(\mathrm{t},{ }^{3} J(\mathrm{H}, \mathrm{H})=7.5 \mathrm{~Hz}, 3 \mathrm{H}\right.$, Indole-H6), $6.70\left(\mathrm{t},{ }^{3} \mathrm{~J}(\mathrm{H}, \mathrm{H})=7.3 \mathrm{~Hz}, 3 \mathrm{H}\right.$, Indole- $\left.\underline{\mathrm{H}} 5\right), 5.99(\mathrm{~s}, 1 \mathrm{H}$, $\left.\mathrm{R}_{3} \mathrm{CH}\right), 2.41 \mathrm{ppm}\left(\mathrm{s}, 9 \mathrm{H}, \mathrm{CH}_{3}\right) .{ }^{13} \mathrm{C}$ NMR (Chart 2 gives a graphical

Chart 2. Assignment of ${ }^{13} \mathrm{C}$ NMR Signals of $(\mathrm{tmim}) \mathrm{Ge}^{-}$(1)

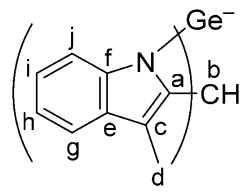

depiction of the assignment) (101 MHz, $\left.\mathrm{CD}_{3} \mathrm{CN}, 25{ }^{\circ} \mathrm{C}\right) \delta=142.0$ $\left(\underline{\mathrm{C}}_{\mathrm{f}}\right), 141.9\left(\underline{\mathrm{C}}_{\mathrm{a}}\right), 131.2\left(\underline{\mathrm{C}}_{\mathrm{e}}\right), 120.0\left(\underline{\mathrm{C}}_{\mathrm{i}}\right), 118.6\left(\underline{\mathrm{C}}_{\mathrm{g}}\right), 117.7\left(\underline{\mathrm{C}}_{\mathrm{h}}\right)$, $112.2\left(\underline{C}_{j}\right), 103.4\left(\underline{C}_{c}\right), 34.2\left(\underline{C}_{b}\right), 8.9 \mathrm{ppm}\left(\underline{C}_{d}\right)$. DOSY NMR $(400$ $\left.\mathrm{MHz}, \mathrm{C}_{4} \mathrm{D}_{8} \mathrm{O}, 25^{\circ} \mathrm{C}\right): \mathrm{D}=7 \times 10^{-18} \mathrm{~m}^{2} / \mathrm{s}$; ESI-MS $\mathrm{C}_{28} \mathrm{H}_{22} \mathrm{~N}_{3} \mathrm{Ge}^{-}$: exp: 474.1060, sim: 474.1031 a.u.. Satisfactory elemental analysis could not be obtained, likely due to THF solvation.

Synthesis of $\mathrm{K}[(\mathrm{tmim}) \mathrm{GeCuCl}]$ (2). To the combined solids $1-\mathrm{K}$ $(30 \mathrm{mg}, 40 \mathrm{wt} \% \mathrm{THF}, 35 \mu \mathrm{mol})$ and $\mathrm{CuCl}(3.5 \mathrm{mg}, 35 \mu \mathrm{mol})$ was added THF $(2 \mathrm{~mL})$, and the suspension was stirred for $60 \mathrm{~min}$, during which the amount of solid increased. The resulting suspension was freed of solvent in vacuo, affording a white powder $(29 \mathrm{mg}, 27 \mathrm{wt} \%$ THF, $35 \mu \mathrm{mol}, 99 \%) .{ }^{1} \mathrm{H}$ NMR $\left(400 \mathrm{MHz}, \mathrm{C}_{4} \mathrm{D}_{8} \mathrm{O}, 25^{\circ} \mathrm{C}\right) \delta=7.96$ $\left(\mathrm{d},{ }^{3} \mathrm{~J}(\mathrm{H}, \mathrm{H})=8.1 \mathrm{~Hz}, 3 \mathrm{H}\right.$, Indole- $\left.\underline{\mathrm{H}} 7\right), 7.26\left(\mathrm{~d},{ }^{3} \mathrm{~J}(\mathrm{H}, \mathrm{H})=7.7 \mathrm{~Hz}\right.$, $3 \mathrm{H}$, Indole- $\underline{\mathrm{H}} 4), 6.90\left(\mathrm{t},{ }^{3} \mathrm{~J}(\mathrm{H}, \mathrm{H})=7.5 \mathrm{~Hz}, 3 \mathrm{H}\right.$, Indole- $\left.\underline{\mathrm{H}} 6\right), 6.77(\mathrm{t}$, ${ }^{3} \mathrm{~J}(\mathrm{H}, \mathrm{H})=7.4 \mathrm{~Hz}, 3 \mathrm{H}$, Indole- $\left.\underline{\mathrm{H}} 5\right), 6.05\left(\mathrm{~s}, 1 \mathrm{H}, \mathrm{R}_{3} \mathrm{C} \underline{\mathrm{H}}\right), 2.43 \mathrm{ppm}(\mathrm{s}$, $\left.9 \mathrm{H}, \mathrm{CH}_{3}\right) .{ }^{13} \mathrm{C}$ NMR $\left(101 \mathrm{MHz}, \mathrm{C}_{4} \mathrm{D}_{8} \mathrm{O}, 25{ }^{\circ} \mathrm{C}\right) \delta=140.5\left({ }^{\mathrm{Ar}} \mathrm{q} \underline{\mathrm{C}}\right)$, $139.8\left({ }^{\mathrm{Ar}} \mathrm{q} C\right), 130.6\left({ }^{\mathrm{Ar}} \mathrm{q} C\right), 118.9\left({ }^{\mathrm{Ar}} \mathrm{CH}\right), 117.3\left({ }^{\mathrm{Ar}} \mathrm{CH}\right), 116.8$ $\left({ }^{\mathrm{Ar}} \underline{\mathrm{C}} \mathrm{H}\right), 111.5\left({ }^{\mathrm{Ar}} \underline{\mathrm{CH}}\right), 102.8\left({ }^{\mathrm{Ar}} \mathrm{q} \underline{\mathrm{C}}\right), 32.7\left(\mathrm{R}_{3} \underline{\mathrm{CH}}\right), 7.8 \mathrm{ppm}\left(\underline{\mathrm{C}}_{3}\right)$; DOSY NMR ( $\left.400 \mathrm{MHz}, \mathrm{C}_{4} \mathrm{D}_{8} \mathrm{O}, 25^{\circ} \mathrm{C}\right): \mathrm{D}=7 \times 10^{-18} \mathrm{~m}^{2} / \mathrm{s}$; ESIMS $\mathrm{C}_{28} \mathrm{H}_{22} \mathrm{~N}_{3} \mathrm{ClGeCu}^{-}$: exp: 572.0092, sim: 572.0009 a.u. Satisfactory elemental analysis could not be obtained, likely due to THF solvation.

Solvolysis of 2 To Form (tmim) GeCu( $\mathrm{MeCN})_{3}$ (3). A solution of 2 $(\sim 10 \mathrm{mg})$ in $\mathrm{CD}_{3} \mathrm{CN}(0.4 \mathrm{~mL})$ was allowed to stand for $16 \mathrm{~h}$, during which crystals of 3 suitable for $\mathrm{X}$-ray diffraction grew. ${ }^{1} \mathrm{H}$ NMR (400 $\left.\mathrm{MHz}, \mathrm{CD}_{3} \mathrm{CN}, 25{ }^{\circ} \mathrm{C}\right) \delta=7.78\left(\mathrm{~d},{ }^{3} \mathrm{~J}(\mathrm{H}, \mathrm{H})=8.1 \mathrm{~Hz}, 3 \mathrm{H}\right.$, IndoleH7), $7.34\left(\mathrm{ddd},{ }^{3} J(\mathrm{H}, \mathrm{H})=7.7 \mathrm{~Hz},{ }^{4} J(\mathrm{H}, \mathrm{H})=1.3 \mathrm{~Hz},{ }^{5} \mathrm{~J}(\mathrm{H}, \mathrm{H})=0.7\right.$ $\mathrm{Hz}, 3 \mathrm{H}$, Indole- $\underline{\mathrm{H}} 4), 6.94\left(\mathrm{t},{ }^{3} \mathrm{~J}(\mathrm{H}, \mathrm{H})=7.5 \mathrm{~Hz}, 3 \mathrm{H}\right.$, Indole- $\left.\underline{\mathrm{H} 6} 6\right), 6.87$ $\left(\mathrm{ddd},{ }^{3} J(\mathrm{H}, \mathrm{H})=7.9 \mathrm{~Hz},{ }^{3} J(\mathrm{H}, \mathrm{H})=6.9 \mathrm{~Hz},{ }^{4} \mathrm{~J}(\mathrm{H}, \mathrm{H})=1.1 \mathrm{~Hz}, 3 \mathrm{H}\right.$, Indole- $\underline{\mathrm{H}} 5), 6.04\left(\mathrm{~s}, 1 \mathrm{H}, \mathrm{R}_{3} \mathrm{CH}\right), 2.42 \mathrm{ppm}\left(\mathrm{s}, 9 \mathrm{H}, \mathrm{CH}_{3}\right) ;{ }^{13} \mathrm{C} \mathrm{NMR}$ $\left(101 \mathrm{MHz}, \mathrm{CD}_{3} \mathrm{CN}, 25^{\circ} \mathrm{C}\right) \delta=141.4\left({ }^{\mathrm{Ar}} \mathrm{qC}\right), 140.8\left({ }^{\mathrm{Ar}} \mathrm{qC}\right), 131.1$ ( $\left.{ }^{\mathrm{Ar}} \mathrm{q} \underline{\mathrm{C}}\right), 120.7\left({ }^{\mathrm{Ar}} \underline{\mathrm{C}} \mathrm{H}\right), 118.9\left({ }^{\mathrm{Ar}} \underline{\mathrm{C}} \mathrm{H}\right), 118.5\left({ }^{\mathrm{Ar}} \underline{\mathrm{C}} \mathrm{H}\right), 112.5\left({ }^{\mathrm{Ar}} \underline{\mathrm{C}} \mathrm{H}\right)$, $104.7\left({ }^{\mathrm{Ar}} \mathrm{q} \mathrm{C}\right), 33.6\left(\mathrm{R}_{3} \underline{\mathrm{CH}}\right), 8.7 \mathrm{ppm}\left(\mathrm{CH}_{3}\right)$.

Synthesis of (tmim) GeCu(MeCN) ${ }_{3}$ (3) from $\mathrm{Cu}(\mathrm{MeCN})_{4} \cdot \mathrm{PF}_{6}$. A solution of $1-\mathrm{K}(32 \mathrm{mg}, 38 \mathrm{wt} \% \mathrm{THF}, 39 \mu \mathrm{mol})$ in acetonitrile $(0.5$ $\mathrm{mL})$ was added to a stirred solution of $\mathrm{Cu}(\mathrm{MeCN})_{4} \cdot \mathrm{PF}_{6}(14 \mathrm{mg}, 39$ $\mu \mathrm{mol})$ in acetonitrile $(0.5 \mathrm{~mL})$. The vial was rinsed with acetonitrile $(2 \times 0.5 \mathrm{~mL})$, and the solution was added to the mixture. Within 5 min, a white solid precipitated. After $3 \mathrm{~h}$, the mixture was filtered and the white residue was washed with acetonitrile $(2 \times 0.5 \mathrm{~mL})$ and freed of solvent in vacuo $(21 \mathrm{mg}, 32 \mu \mathrm{mol}, 83 \%) .{ }^{1} \mathrm{H}$ NMR $(400 \mathrm{MHz}$ $\left.\mathrm{C}_{4} \mathrm{H}_{8} \mathrm{O}+\mathrm{C}_{6} \mathrm{D}_{6}, 25^{\circ} \mathrm{C}\right) \delta=7.62\left(\mathrm{~d},{ }^{3} J(\mathrm{H}, \mathrm{H})=8.0 \mathrm{~Hz}, 3 \mathrm{H}\right.$, IndoleH7), 7.28 (d*, Indole- $\underline{\mathrm{H}} 4), 6.86\left(\mathrm{t},{ }^{3} \mathrm{~J}(\mathrm{H}, \mathrm{H})=7.5 \mathrm{~Hz}, 3 \mathrm{H}\right.$, Indole$\underline{\mathrm{H}} 6), 6.79\left(\mathrm{t},{ }^{3} \mathrm{~J}(\mathrm{H}, \mathrm{H})=7.3 \mathrm{~Hz}, 3 \mathrm{H}\right.$, Indole- $\left.\underline{\mathrm{H}} 5\right), 6.04\left(\mathrm{~s}, 1 \mathrm{H}, \mathrm{R}_{3} \mathrm{CH}\right)$, $2.42 \mathrm{ppm}\left(\mathrm{s}, 9 \mathrm{H}, \mathrm{CH}_{3}\right)$. *doublet overlaps with $\mathrm{C}_{6} \mathrm{D}_{5} \mathrm{H}$. ${ }^{1} \mathrm{H}$ NMR $\left(400 \mathrm{MHz}, \mathrm{CD}_{3} \mathrm{CN}, 25{ }^{\circ} \mathrm{C}\right) \delta=7.77\left(\mathrm{~d},{ }^{3} \mathrm{~J}(\mathrm{H}, \mathrm{H})=8.1 \mathrm{~Hz}, 3 \mathrm{H}\right.$, Indole- $\underline{\mathrm{H}} 7), 7.34\left(\mathrm{~d},{ }^{3} \mathrm{~J}(\mathrm{H}, \mathrm{H})=7.7 \mathrm{~Hz}, 3 \mathrm{H}\right.$, Indole- $\left.\underline{\mathrm{H}} 4\right), 6.94(\mathrm{t}$, ${ }^{3} \mathrm{~J}(\mathrm{H}, \mathrm{H})=7.5 \mathrm{~Hz}, 3 \mathrm{H}$, Indole- $\left.\underline{\mathrm{H}} 6\right), 6.87\left(\mathrm{t},{ }^{3} \mathrm{~J}(\mathrm{H}, \mathrm{H})=7.3 \mathrm{~Hz}, 3 \mathrm{H}\right.$, 
Indole- $\underline{\mathrm{H}} 5), 6.04$ (s, 1H, $\left.\mathrm{R}_{3} \mathrm{CH}\right), 2.42 \mathrm{ppm}\left(\mathrm{s}, 9 \mathrm{H}, \mathrm{C}_{3}\right) .{ }^{13} \mathrm{C} \mathrm{NMR}$ $\left(101 \mathrm{MHz}, \mathrm{CD}_{3} \mathrm{CN}, 25{ }^{\circ} \mathrm{C}\right) \bar{\delta}=141.4\left({ }^{\mathrm{Ar}} \mathrm{qC}\right), 140.8\left({ }^{\mathrm{Ar}} \mathrm{qC}\right), 131.1$ ( $\left.{ }^{\mathrm{Ar}} \mathrm{q} \underline{\mathrm{C}}\right), 120.7\left({ }^{\mathrm{Ar}} \underline{\mathrm{CH}}\right), 118.9\left({ }^{\mathrm{Ar}} \underline{\mathrm{C}} \mathrm{H}\right), 118.5\left({ }^{\mathrm{Ar}} \mathrm{CH}\right), 112.4\left({ }^{\mathrm{Ar}} \underline{\mathrm{C}} \mathrm{H}\right)$, $104.7\left({ }^{\mathrm{Ar}} \mathrm{q} \underline{\mathrm{C}}\right), 33.6\left(\mathrm{R}_{3} \underline{\mathrm{CH}}\right), 8.7 \mathrm{ppm}\left(\underline{\mathrm{C}}_{3}\right)$. Satisfactory elemental analysis could not be obtained, likely due to loss of coordinated $\mathrm{MeCN}$.

Synthesis of $\mathrm{K}\left[(\mathrm{tmim}) \mathrm{GeFe}(\mathrm{CO})_{4}\right]$ (4). A solution of $1-\mathrm{K}(122 \mathrm{mg}$, $62 \mathrm{wt} \% \mathrm{THF}, 0.15 \mathrm{mmol})$ in THF $(13 \mathrm{~mL})$ was added to an orange suspension of $\mathrm{Fe}_{2}(\mathrm{CO})_{9}(54 \mathrm{mg}, 147 \mu \mathrm{mol})$ in THF $(5 \mathrm{~mL})$ and stirred for $30 \mathrm{~min}$. The solution was freed of solvent in vacuo to a burgundy solid, which was dissolved in THF $(1.5 \mathrm{~mL})$ and cooled to $-35{ }^{\circ} \mathrm{C}$. Cold hexane $(15 \mathrm{~mL})$ was added, and after $16 \mathrm{~h}$ at $-35^{\circ} \mathrm{C}$, the suspension was filtered and the white solid was dried in vacuo (105 mg, 15 wt \% THF, $0.13 \mathrm{mmol}, 88 \%) .{ }^{1} \mathrm{H}$ NMR (400 MHz, $\left.\mathrm{CD}_{3} \mathrm{CN}, 70{ }^{\circ} \mathrm{C}\right) \delta=8.00\left(\mathrm{~d},{ }^{3} \mathrm{~J}(\mathrm{H}, \mathrm{H})=8.2 \mathrm{~Hz}, 3 \mathrm{H}\right), 7.41(\mathrm{~d}$, $\left.{ }^{3} J(\mathrm{H}, \mathrm{H})=7.8 \mathrm{~Hz}, 3 \mathrm{H}\right), 7.04\left(\mathrm{ddd},{ }^{3} J(\mathrm{H}, \mathrm{H})=8.3 \mathrm{~Hz},{ }^{3} J(\mathrm{H}, \mathrm{H})=6.8\right.$ $\left.\mathrm{Hz},{ }^{4} J(\mathrm{H}, \mathrm{H})=1.5 \mathrm{~Hz}, 3 \mathrm{H}\right), 6.96\left(\mathrm{t},{ }^{3} \mathrm{~J}(\mathrm{H}, \mathrm{H})=7.4 \mathrm{~Hz}, 3 \mathrm{H}\right), 6.17(\mathrm{~s}$, $1 \mathrm{H}), 2.49 \mathrm{ppm}(\mathrm{s}, 8 \mathrm{H}) .{ }^{1} \mathrm{H}$ NMR $\left(400 \mathrm{MHz}, \mathrm{CD}_{3} \mathrm{CN}, 25^{\circ} \mathrm{C}\right) \delta=$ $7.96\left(\mathrm{dt},{ }^{3} \mathrm{~J}(\mathrm{H}, \mathrm{H})=8.3 \mathrm{~Hz},{ }^{4} \mathrm{~J}(\mathrm{H}, \mathrm{H})=0.9 \mathrm{~Hz}, 3 \mathrm{H}\right.$, Indole- $\left.\underline{\mathrm{H}} 7\right), 7.40$ $\left(\mathrm{ddd},{ }^{3} J(\mathrm{H}, \mathrm{H})=7.8 \mathrm{~Hz},{ }^{4} J(\mathrm{H}, \mathrm{H})=1.3 \mathrm{~Hz},{ }^{5} \mathrm{~J}(\mathrm{H}, \mathrm{H})=0.7 \mathrm{~Hz}, 3 \mathrm{H}\right.$, Indole- $\underline{\mathrm{H}} 4), 7.04\left(\mathrm{ddd},{ }^{3} \mathrm{~J}(\mathrm{H}, \mathrm{H})=8.3 \mathrm{~Hz},{ }^{3} \mathrm{~J}(\mathrm{H}, \mathrm{H})=7.0 \mathrm{~Hz},{ }^{4} J(\mathrm{H}, \mathrm{H})\right.$ $=1.3 \mathrm{~Hz}, 3 \mathrm{H}$, Indole- $\mathrm{H} 6), 6.95\left(\mathrm{ddd},{ }^{3} J(\mathrm{H}, \mathrm{H})=7.9 \mathrm{~Hz},{ }^{3} J(\mathrm{H}, \mathrm{H})=\right.$ $7.0 \mathrm{~Hz},{ }^{4} \mathrm{~J}(\mathrm{H}, \mathrm{H})=1.1 \mathrm{~Hz}, 3 \mathrm{H}$, Indole- $\left.\underline{\mathrm{H}} 5\right), 6.15(\mathrm{~s}, 1 \mathrm{H}), 2.46 \mathrm{ppm}(\mathrm{s}$, 9H). ${ }^{1} \mathrm{H}$ NMR $\left(400 \mathrm{MHz}, \mathrm{CD}_{3} \mathrm{CN},-40{ }^{\circ} \mathrm{C}\right) \delta=7.94\left(\mathrm{dt},{ }^{3} \mathrm{~J}(\mathrm{H}, \mathrm{H})=\right.$ $\left.8.3 \mathrm{~Hz},{ }^{4} J(\mathrm{H}, \mathrm{H})=0.9 \mathrm{~Hz}, 3 \mathrm{H}\right), 7.40\left(\mathrm{ddd},{ }^{3} J(\mathrm{H}, \mathrm{H})=7.8 \mathrm{~Hz}\right.$, $\left.{ }^{4} J(\mathrm{H}, \mathrm{H})=1.3 \mathrm{~Hz},{ }^{5} J(\mathrm{H}, \mathrm{H})=0.7 \mathrm{~Hz}, 3 \mathrm{H}\right), 7.04\left(\mathrm{ddd},{ }^{3} J(\mathrm{H}, \mathrm{H})=8.3\right.$ $\left.\mathrm{Hz},{ }^{3} J(\mathrm{H}, \mathrm{H})=7.0 \mathrm{~Hz},{ }^{4} \mathrm{~J}(\mathrm{H}, \mathrm{H})=1.3 \mathrm{~Hz}, 3 \mathrm{H}\right), 6.95\left(\mathrm{ddd},{ }^{3} \mathrm{~J}(\mathrm{H}, \mathrm{H})=\right.$ $\left.7.9 \mathrm{~Hz},{ }^{3} J(\mathrm{H}, \mathrm{H})=7.0 \mathrm{~Hz},{ }^{4} J(\mathrm{H}, \mathrm{H})=1.1 \mathrm{~Hz}, 3 \mathrm{H}\right), 6.15(\mathrm{~s}, 1 \mathrm{H}), 2.45$ $\operatorname{ppm}(\mathrm{s}, 9 \mathrm{H}) \cdot{ }^{13} \mathrm{C}$ NMR $\left(101 \mathrm{MHz}, \mathrm{CD}_{3} \mathrm{CN},-40{ }^{\circ} \mathrm{C}\right): \delta=222.6$ ( ${ }^{\mathrm{ax}} \underline{\mathrm{CO}}$ ), 212.2 ( $\left.{ }^{\mathrm{eq}} \underline{\mathrm{CO}}\right), 140.3$ ( $\left.{ }^{\mathrm{Ar}} \mathrm{q} \underline{\mathrm{C}}\right), 139.0\left({ }^{\mathrm{Ar}} \mathrm{q} \underline{\mathrm{C}}\right), 130.4\left({ }^{\mathrm{Ar}} \mathrm{q} \underline{\mathrm{C}}\right)$, $121.3\left({ }^{\mathrm{Ar}} \mathrm{CH}\right), 119.0\left(2{ }^{\mathrm{Ar}} \mathrm{CH}\right), 112.2\left({ }^{\mathrm{Ar}} \mathrm{C} H\right), 105.6\left({ }^{\mathrm{Ar}} \mathrm{q} C\right), 32.4$ $\left(\mathrm{R}_{3} \mathrm{CH}\right), 8.4 \mathrm{ppm}\left(\mathrm{CH}_{3}\right) \cdot{ }^{13} \mathrm{C}$ NMR $\left(101 \mathrm{MHz}, \mathrm{CD}_{3} \mathrm{CN}, 25^{\circ} \mathrm{C}\right): \delta=$ 215.1 (fwhm $=125 \mathrm{~Hz}, \underline{\mathrm{CO}}), 141.0\left({ }^{\mathrm{Ar}} \mathrm{qC}\right), 139.9\left({ }^{\mathrm{Ar}} \mathrm{qC}\right), 131.2$ ( $\left.{ }^{\mathrm{Ar}} \mathrm{q} \underline{\mathrm{C}}\right), 121.5\left({ }^{\mathrm{Ar}} \underline{\mathrm{C}} \mathrm{H}\right), 119.3\left({ }^{\mathrm{Ar}} \underline{\mathrm{C}} \mathrm{H}\right), 119.2\left({ }^{\mathrm{Ar}} \underline{\mathrm{C}} \mathrm{H}\right), 112.9\left({ }^{\mathrm{Ar}} \underline{\mathrm{C}} \mathrm{H}\right)$, 105.6 ( $\left.{ }^{\mathrm{Ar}} \mathrm{q} \underline{\mathrm{C}}\right), 33.1\left(\mathrm{R}_{3} \underline{\mathrm{CH}}\right), 8.6 \mathrm{ppm}\left(\mathrm{CH}_{3}\right) .{ }^{13} \mathrm{C}$ NMR $(101 \mathrm{MHz}$, $\left.\mathrm{CD}_{3} \mathrm{CN}, 70{ }^{\circ} \mathrm{C}\right): \delta=215.5(\underline{\mathrm{CO}}), 141.6\left({ }^{\mathrm{Ar}} \mathrm{qC}\right), 140.5\left({ }^{\mathrm{Ar}} \mathrm{qC}\right), 131.8$ ( $\left.{ }^{\mathrm{Ar}} \mathrm{q} \underline{\mathrm{C}}\right), 121.6\left({ }^{\mathrm{Ar}} \underline{\mathrm{C}} \mathrm{H}\right), 119.5\left({ }^{\mathrm{Ar}} \underline{\mathrm{C}} \mathrm{H}\right), 119.4\left({ }^{\mathrm{Ar}} \underline{\mathrm{C}} \mathrm{H}\right), 113.3\left({ }^{\mathrm{Ar}} \underline{\mathrm{C}} \mathrm{H}\right)$, 105.7 ( $\left.{ }^{\mathrm{Ar}} \mathrm{q} \underline{\mathrm{C}}\right), 33.7\left(\mathrm{R}_{3} \underline{\mathrm{CH}}\right), 8.8 \mathrm{ppm}\left(\underline{\mathrm{CH}}_{3}\right)$; ESI-MS $\mathrm{C}_{32} \mathrm{H}_{22} \mathrm{O}_{4} \mathrm{Ge}-$ $\mathrm{N}_{3} \mathrm{Fe}^{-}$: exp: 642.0437 , sim: 642.0180 a.u.; IR (THF): $\tilde{\nu}=2037,1954$, $1933 \mathrm{~cm}^{-1}$. Satisfactory elemental analysis could not be obtained, likely due to THF solvation.

Interaction between 1 and $\mathrm{FeCl}_{2}$. The combined solids $1-\mathrm{K}$ (30 $\mathrm{mg}, 40 \mathrm{wt} \% \mathrm{THF}, 35 \mu \mathrm{mol})$ and $\mathrm{FeCl}_{2}(4.6 \mathrm{mg}, 36 \mu \mathrm{mol})$ were dissolved in THF $(2 \mathrm{~mL})$ and stirred for $60 \mathrm{~min} .{ }^{1} \mathrm{H}$ NMR $(400 \mathrm{MHz}$, $\left.\mathrm{C}_{4} \mathrm{H}_{8} \mathrm{O}+\mathrm{C}_{6} \mathrm{D}_{6}, 25{ }^{\circ} \mathrm{C}\right) \delta^{*}=8.08(\mathrm{br} \mathrm{s}, 3 \mathrm{H}), 7.23\left(\mathrm{~d},{ }^{3} \mathrm{~J}(\mathrm{H}, \mathrm{H})=7.6\right.$ $\mathrm{Hz}, 3 \mathrm{H}), 6.83\left(\mathrm{br} \mathrm{d},{ }^{3} J(\mathrm{H}, \mathrm{H})=6.8 \mathrm{~Hz}, 3 \mathrm{H}\right), 6.73\left(\mathrm{t},{ }^{3} J(\mathrm{H}, \mathrm{H})=7.1\right.$ $\mathrm{Hz}, 3 \mathrm{H}), 5.90(\mathrm{~s}, 1 \mathrm{H}), 2.40 \mathrm{ppm}(\mathrm{s}, 9 \mathrm{H}) .{ }^{*}$ relative to $\mathrm{C}_{6} \mathrm{D}_{5} \mathrm{H}$ in THF (7.32 $\mathrm{ppm})$.

\section{ASSOCIATED CONTENT}

\section{S Supporting Information}

The Supporting Information is available free of charge on the ACS Publications website at DOI: 10.1021/acs.organomet.8b00630.

Crystallographic data, spectroscopic data, and computational details (PDF)

Coordinates of the computed structures (XYZ)

\section{Accession Codes}

CCDC 1848178-1848181 contain the supplementary crystallographic data for this paper. These data can be obtained free of charge via www.ccdc.cam.ac.uk/data_request/cif, or by emailing data_request@ccdc.cam.ac.uk, or by contacting The Cambridge Crystallographic Data Centre, 12 Union Road, Cambridge CB2 1EZ, UK; fax: +44 1223336033.

\section{AUTHOR INFORMATION}

\section{Corresponding Author}

*E-mail: M.Moret@uu.nl.

ORCID $\odot$

Léon Witteman: 0000-0003-2189-830X

Marc-Etienne Moret: 0000-0002-3137-6073

Notes

The authors declare no competing financial interest.

\section{ACKNOWLEDGMENTS}

Support with NMR spectroscopic analysis by Dr. J. T. B. H. Jastrzebski is gratefully acknowledged. We acknowledge funding from the European Union Seventh Framework Programme (FP7/2007-2013) under grant agreement PIIFGA-2012-327306 (IIF-Marie Curie grant awarded to M.E.M.), the Dutch National Research School Combination Catalysis (NRSC-C), and the Sectorplan Natuur- en Scheikunde (Tenure-track grant at Utrecht University). This work was sponsored by NWO Exacte en Natuurwetenschappen (Physical Sciences) for the use of supercomputer facilities, with financial support from The Netherlands Organization for Scientific Research (NWO). The X-ray diffractometer was financed by the NWO.

\section{REFERENCES}

(1) Benedek, Z.; Szilvási, T. Theoretical Assessment of Low-Valent Germanium Compounds as Transition Metal Ligands: Can They Be Better than Phosphines or NHCs? Organometallics 2017, 36, 15911600.

(2) Benedek, Z.; Szilvási, T. Can Low-Valent Silicon Compounds Be Better Transition Metal Ligands than Phosphines and NHCs? RSC Adv. 2015, 5, 5077-5086.

(3) Kilian, M.; Wadepohl, H.; Gade, L. H. Triamidostannates(II) as Sterically Demanding Ligands for Rhodium and Iridium. Organometallics 2008, 27, 524-533.

(4) Fürstner, A.; Krause, H.; Lehmann, C. W. Preparation, Structure and Catalytic Properties of a Binuclear $\operatorname{Pd}(0)$ Complex with Bridging Silylene Ligands. Chem. Commun. 2001, 80, 2372-2373.

(5) (a) Gallego, D.; Brück, A.; Irran, E.; Meier, F.; Kaupp, M.; Driess, M.; Hartwig, J. F. From Bis(Silylene) and Bis(Germylene) Pincer-Type Nickel(II) Complexes to Isolable Intermediates of the Nickel-Catalyzed Sonogashira Cross-Coupling Reaction. J. Am. Chem. Soc. 2013, 135, 15617-15626. (b) Álvarez-Rodríguez, L.; Cabeza, J. A.; García-Álvarez, P.; Pérez-Carreño, E. Ruthenium Carbene Complexes Analogous to Grubbs-I Catalysts Featuring Germylenes as Ancillary Ligands. Organometallics 2018, 37, 3399-3406. (c) Álvarez-Rodríguez, L.; Cabeza, J. A.; Fernández-Colinas, J. M.; García-Álvarez, P.; Polo, D. Amidinatogermylene Metal Complexes as Homogeneous Catalysts in Alcoholic Media. Organometallics 2016, 35, 2516-2523. (d) Sharma, M. K.; Singh, D.; Mahawar, P.; Yadav, R.; Nagendran, S. Catalytic cyanosilylation using germylene stabilized platinum(II) dicyanide. Dalton Trans. 2018, 47, 5943-5947.

(6) Wang, W.; Inoue, S.; Enthaler, S.; Driess, M. Bis(Silylenyl) and Bis(Germylenyl) Substituted Ferrocenes: Synthesis, Structure, and Catalytic Applications of Bidentate Silicon(II)-Cobalt Complexes. Angew. Chem., Int. Ed. 2012, 51, 6167-6171.

(7) Metsänen, T. T.; Gallego, D.; Szilvási, T.; Driess, M.; Oestreich, M. Peripheral Mechanism of a Carbonyl Hydrosilylation Catalysed by an SiNSi Iron Pincer Complex. Chem. Sci. 2015, 6, 7143-7149.

(8) Gallego, D.; Inoue, S.; Blom, B.; Driess, M. Highly Electron-Rich Pincer-Type Iron Complexes Bearing Innocent Bis(Metallylene)Pyridine Ligands: Syntheses, Structures, and Catalytic Activity. Organometallics 2014, 33, 6885-6897.

(9) Zhang, M.; Liu, X.; Shi, C.; Ren, C.; Ding, Y.; Roesky, H. W. The Synthesis of $\left(\eta^{3}-\mathrm{C}_{3} \mathrm{H}_{5}\right) \mathrm{Pd}\left\{\mathrm{Si}[\mathrm{N}(t \mathrm{Bu}) \mathrm{CH}]_{2}\right\} \mathrm{Cl}$ and the Catalytic 
Property for Heck Reaction. Z. Anorg. Allg. Chem. 2008, 634, 17551758.

(10) Brück, A.; Gallego, D.; Wang, W.; Irran, E.; Driess, M.; Hartwig, J. F. Pushing the $\sigma$-Donor Strength in Iridium Pincer Complexes: Bis(Silylene) and Bis(Germylene) Ligands Are Stronger Donors than Bis(Phosphorus(III)) Ligands. Angew. Chem., Int. Ed. 2012, 51, 11478-11482.

(11) Blom, B.; Enthaler, S.; Inoue, S.; Irran, E.; Driess, M. ElectronRich N-Heterocyclic Silylene (NHSi)-Iron Complexes: Synthesis, Structures, and Catalytic Ability of an Isolable Hydridosilylene-Iron Complex. J. Am. Chem. Soc. 2013, 135, 6703-6713.

(12) Cordero, B.; Gómez, V.; Platero-Prats, A. E.; Revés, M.; Echeverría, J.; Cremades, E.; Barragán, F.; Alvarez, S. Covalent Radii Revisited. Dalton Trans. 2008, No. 21, 2832-2838.

(13) Li, H.; Aquino, A. J. A.; Cordes, D. B.; Hase, W. L.; Krempner, C. Electronic Nature of Zwitterionic Alkali Metal Methanides, Silanides and Germanides - A Combined Experimental and Computational Approach. Chem. Sci. 2017, 8, 1316-1328.

(14) Lee, G.; West, R.; Muller, T. Bis[Bis(Trimethylsilyl)Amino]Silylene, an Unstable Divalent Silicon Compound. J. Am. Chem. Soc. 2003, 125, 8114-8115.

(15) Levason, W.; Reid, G.; Zhang, W. Coordination Complexes of Silicon and Germanium Halides with Neutral Ligands. Coord. Chem. Rev. 2011, 255, 1319-1341.

(16) Al-Rafia, S. M. I.; McDonald, R.; Ferguson, M. J.; Rivard, E. Preparation of Stable Low-Oxidation-State Group 14 Element Amidohydrides and Hydride-Mediated Ring-Expansion Chemistry of N-Heterocyclic Carbenes. Chem. - Eur. J. 2012, 18, 13810-13820.

(17) Protchenko, A. V.; Birjkumar, K. H.; Dange, D.; Schwarz, A. D.; Vidovic, D.; Jones, C.; Kaltsoyannis, N.; Mountford, P.; Aldridge, S. A Stable Two-Coordinate Acyclic Silylene. J. Am. Chem. Soc. 2012, 134, 6500-6503.

(18) Lui, M. W.; Merten, C.; Ferguson, M. J.; McDonald, R.; Xu, Y.; Rivard, E. Contrasting Reactivities of Silicon and Germanium Complexes Supported by an N -Heterocyclic Guanidine Ligand. Inorg. Chem. 2015, 54, 2040-2049.

(19) Driess, M.; Yao, S.; Brym, M.; van Wüllen, C.; Lentz, D. A New Type of N-Heterocyclic Silylene with Ambivalent Reactivity. J. Am. Chem. Soc. 2006, 128, 9628-9629.

(20) Yao, S.; Xiong, Y.; Driess, M. Zwitterionic and Donor-Stabilized N-Heterocyclic Silylenes (NHSis) for Metal-Free Activation of Small Molecules. Organometallics 2011, 30, 1748-1767.

(21) Meltzer, A.; Inoue, S.; Präsang, C.; Driess, M. Steering S-H and $\mathrm{N}-\mathrm{H}$ Bond Activation by a Stable N-Heterocyclic Silylene: Different Addition of $\mathrm{H}_{2} \mathrm{~S}, \mathrm{NH}_{3}$ and Organoamines on a Silicon(II) Ligand versus Its $\mathrm{Si}(\mathrm{II}) \rightarrow \mathrm{Ni}(\mathrm{CO})_{3}$ Complex. J. Am. Chem. Soc. 2010, 132, 3038-3046.

(22) Schmidt, M.; Blom, B.; Szilvási, T.; Schomäcker, R.; Driess, M. Improving the Catalytic Activity in the Rhodium-Mediated Hydroformylation of Styrene by a Bis(N-Heterocyclic Silylene) Ligand. Eur. J. Inorg. Chem. 2017, 2017, 1284-1291.

(23) Witteman, L.; Evers, T.; Lutz, M.; Moret, M. A Free Silanide from Nucleophilic Substitution at Silicon(II). Chem. - Eur. J. 2018, 24, $12236-12240$.

(24) Filippou, A. C.; Steck, R.; Kociok-Köhn, G. Triazidogermyl Complexes of Tungsten: Synthesis, Crystal Structure and Hydrolysis to a Metallocyclotrigermoxane. J. Chem. Soc., Dalton Trans. 1999, No. 14, 2267-2268.

(25) (a) Contel, M.; Hellmann, K. W.; Gade, L. H.; Scowen, I. J.; McPartlin, M.; Laguna, M. Triamidogerma- and Triamidostannaaurates(I): First Structural Characterization of a $\mathrm{Ge}-\mathrm{Au}-\mathrm{Ge}$ Unit. Inorg. Chem. 1996, 35, 3713-3715. (b) Gade, L. H. Tripodal Triamidometallates of the Heavy Group 14 Elements: Inorganic Cages with Remarkable "Ligand Properties. Eur. J. Inorg. Chem. 2002, 2002, 1257-1268.

(26) Coste, S. C.; Vlaisavljevich, B.; Freedman, D. E. Magnetic Anisotropy from Main-Group Elements: Halides versus Group 14 Elements. Inorg. Chem. 2017, 56, 8195-8202.
(27) Peerless, B.; Keane, T.; Meijer, A. J. H. M.; Portius, P. Homoleptic Low-Valent Polyazides of Group 14 Elements. Chem. Commun. 2015, 51, 7435-7438.

(28) Steiner, A.; Stalke, D. Sodium Tri(Pyrazol-1-yl)-Germanate and -Stannate: New Tridentate 'Claw-Ligands' Containing Group 14 Metals. J. Chem. Soc., Chem. Commun. 1993, No. 22, 1702-1704.

(29) Veith, M.; Schütt, O.; Huch, V. The First Crystal Structure of a Germanium(II) Amide with a Germanium - Lithium Bond and Its Behavior Towards Oxygen and Water. Angew. Chem., Int. Ed. 2000, 39, 601-604.

(30) Fernández, I.; Oña-Burgos, P.; Armbruster, F.; Krummenacher, I.; Breher, F. ${ }^{7} \mathrm{Li},{ }^{15} \mathrm{~N}$ Heteronuclear Multiple Quantum Shift Correlation-a Fast and Reliable 2D NMR Method on Natural Abundant Nuclei. Chem. Commun. 2009, 1, 2586-2588.

(31) Barnard, T. S.; Mason, M. R. Synthesis, Structure, and Coordination Chemistry of the Bicyclic $\pi$-Acid Phosphatri(3-Methylindolyl)Methane. Organometallics 2001, 20, 206-214.

(32) (a) von Dobeneck, H.; Prietzel, H. Further Observations on Reaction between Aldehydes and Indole Derivatives. Hoppe-Seyler's Z. Physiol. Chem. 1955, 299, 214-226. (b) Mason, M. R.; Barnard, T. S.; Segla, M. F.; Xie, B.; Kirschbaum, K. Di- and triindolylmethanes: molecular structures and spectroscopic characterization of potentially bidentate and tridentate ligands. J. Chem. Crystallogr. 2003, 33, 531540.

(33) Steiner, A.; Stalke, D. Poly(Pyrazolyl)Germanium(II) and -Tin(II) Derivatives-Tuneable Monoanionic Ligands and Dinuclear Cationic Cages. Inorg. Chem. 1995, 34, 4846-4853.

(34) Filippou, A. C.; Winter, J. G.; Kociok-Kohn, G.; Troll, C.; Hinz, I. Electron-Rich Trichlorogermyl Complexes of Molybdenum and Tungsten Bearing a Cyclopentadienyl Ligand: Synthesis, Crystal Structures, and Cyclic Voltammetric Studies. Organometallics 1999, 18, 2649-2659.

(35) Bent, H. A. An Appraisal of Valence-Bond Structures and Hybridization in Compounds of the First-Row Elements. Chem. Rev. 1961, 61, 275-311.

(36) Khrustalev, V. N.; Antipin, M. Y.; Zemlyansky, N. N.; Borisova, I. V.; Ustynyuk, Y. A.; Lunin, V. V.; Izod, K. The Germanium(II) Ate Complex $\left[\mathrm{Ph}_{3} \mathrm{PiPr}\right]\left[\mathrm{Ge}(\mathrm{OCOMe})_{3}\right]$ : The First Structurally Characterized Compound Containing a Discrete $\left[\mathrm{E}^{14(\mathrm{II})} \mathrm{O}_{3}\right]^{(-)}\left(\mathrm{E}^{14(\mathrm{II})}=\mathrm{Si}\right.$, $\mathrm{Ge}, \mathrm{Sn}$ or $\mathrm{Pb}$ ) Anion. Appl. Organomet. Chem. 2005, 19, 360-362.

(37) Nogai, S.; Schriewer, A.; Schmidbaur, H. Reactions of Trichlorogermane $\mathrm{HGeCl}_{3}$ and Dichlorogallane $\mathrm{HGaCl}_{2}$ with Pyridine Donors. Dalton Trans. 2003, 16, 3165-3171.

(38) Kersting, B.; Krebs, B. Syntheses and Structures of Germanium(II) and Germanium(IV) Thiolate and Selenolate Complexes: $\left[\mathrm{Et}_{4} \mathrm{~N}\right]\left[\mathrm{Ge}(\mathrm{SPh})_{3}\right], \quad\left[\mathrm{Ph}_{4} \mathrm{P}\right]\left[\mathrm{Ge}(\mathrm{SePh})_{3}\right], \quad\left[\mathrm{Ph}_{4} \mathrm{P}\right]_{2}\left[\mathrm{Ge}_{2}\left(\mathrm{SCH}_{2}-\right.\right.$ $\left.\left.\mathrm{CH}_{2} \mathrm{~S}\right)_{3}\right], \mathrm{Ge}\left(\mathrm{S}-4-\mathrm{MeC}_{6} \mathrm{H}_{4}\right)_{4}$ and $\mathrm{Ge}\left(\mathrm{Se}-2,4,6-\mathrm{Me}_{3} \mathrm{C}_{6} \mathrm{H}_{2}\right)_{4}$ Examples of the First Anionic Germanium(II) Complexes. Inorg. Chem. 1994, 33, 3886-3892.

(39) Orlov, N. A.; Bochkarev, L. N.; Nikitinsky, A. V.; Zhiitsov, S. F.; Zakharov, L. N.; Fukin, G. K.; Khorshev, S. Ya. Synthesis and Crystal Structure of Cationic Complex of Ytterbium with Organogermanium Cuprate Anions $\left\{\left[\mathrm{Yb}(\mathrm{THF})_{6}\right]^{2+}\left[\left(\mathrm{Ph}_{3} \mathrm{Ge}\right)_{2} \mathrm{Cu}\right]_{2}{ }^{-}\right\} \cdot 2 \mathrm{THF}$. J. Organomet. Chem. 1997, 547, 65-69.

(40) Zhao, N.; Zhang, J.; Yang, Y.; Zhu, H.; Li, Y.; Fu, G. $\beta$ Diketiminate Germylene-Supported Pentafluorophenylcopper(I) and -Silver(I) Complexes $\left[\mathrm{LGe}(\mathrm{Me})\left(\mathrm{CuC}_{6} \mathrm{~F}_{5}\right)_{\mathrm{n}}\right]_{2}(\mathrm{n}=1,2)$, LGe[C$\left.\left(\mathrm{SiMe}_{3}\right) \mathrm{N}_{2}\right] \mathrm{AgC}_{6} \mathrm{~F}_{5}$ and $\left\{\mathrm{LGe}\left[\mathrm{C}\left(\mathrm{SiMe}_{3}\right) \mathrm{N}_{2}\right]\left(\mathrm{AgC}_{6} \mathrm{~F}_{5}\right)_{2}\right\}_{2}(\mathrm{~L}=\mathrm{HC}-$ $\left.\left[\mathrm{C}(\mathrm{Me}) \mathrm{N}-2,6-i \mathrm{Pr}_{2} \mathrm{C}_{6} \mathrm{H}_{3}\right]_{2}\right)$ : Synthesis and Structural Characterization. Inorg. Chem. 2012, 51, 8710-8718.

(41) Ferro, L.; Hitchcock, P. B.; Coles, M. P.; Fulton, J. R. Reactivity of Divalent Germanium Alkoxide Complexes Is in Sharp Contrast to the Heavier Tin and Lead Analogues. Inorg. Chem. 2012, 51, 15441551.

(42) Yadav, D.; Siwatch, R. K.; Sinhababu, S.; Nagendran, S. Aminotroponiminato(Chloro)Germylene Stabilized Copper(I) Iodide Complexes: Synthesis and Structure. Inorg. Chem. 2014, 53, 600-606. 
(43) Yadav, D.; Kumar Siwatch, R.; Sinhababu, S.; Karwasara, S.; Singh, D.; Rajaraman, G.; Nagendran, S. Digermylene Oxide Stabilized Group 11 Metal Iodide Complexes. Inorg. Chem. 2015, 54, 11067-11076.

(44) York, J. T.; Young, V. G.; Tolman, W. B. Heterobimetallic Activation of Dioxygen: Characterization and Reactivity of Novel $\mathrm{Cu}(\mathrm{I})-\mathrm{Ge}(\mathrm{II})$ Complexes. Inorg. Chem. 2006, 45, 4191-4198.

(45) Hlina, J.; Arp, H.; Walewska, M.; Flörke, U.; Zangger, K.; Marschner, C.; Baumgartner, J. Coordination Chemistry of Cyclic Disilylated Germylenes and Stannylenes with Group 11 Metals. Organometallics 2014, 33, 7069-7077.

(46) Orlov, N. A.; Bochkarev, L. N.; Nikitinsky, A. V.; Kropotova, V. Y.N.; Zakharov, L. N.; Fukin, G. K.; Khorshev, S. Y. Synthesis of Germylcopper Compounds by Hydride Method. Crystal Structure of $\left(\mathrm{C}_{6} \mathrm{~F}_{5}\right)_{3} \mathrm{GeCu}\left(\mathrm{PPh}_{3}\right)_{2}$. J. Organomet. Chem. 1998, 560, 21-25.

(47) Piers, E.; Lemieux, R. E. D. Reaction of (Trimethylgermyl) Copper(I) Dimethyl Sulfide with Acyl Chlorides: Efficient Syntheses of Functionalized Acyltrimethylgermanes. Organometallics 1995, 14, $5011-5012$

(48) Glockling, F.; Hooton, K. A. Triphenylgermyl Complexes of Copper, Silver, and Gold. J. Chem. Soc. 1962, 2658-2661.

(49) Barnard, T. S.; Mason, M. R. Hindered Axial-Equatorial Carbonyl Exchange in an $\mathrm{Fe}(\mathrm{CO})_{4}\left(\mathrm{PR}_{3}\right)$ Complex of a Rigid Bicyclic Phosphine. Inorg. Chem. 2001, 40, 5001-5009.

(50) Couzijn, E. P. A.; Slootweg, J. C.; Ehlers, A. W.; Lammertsma, K. Stereomutation of Pentavalent Compounds: Validating the Berry Pseudorotation, Redressing Ugi's Turnstile Rotation, and Revealing the Two- and Three-Arm Turnstiles. J. Am. Chem. Soc. 2010, 132, 18127-18140.

(51) Armarego, W. L. F.; Chai, C. L. L. Purification of Laboratory Chemicals, 5th ed.; Butterworth-Heinemann: Amsterdam, 2003.

(52) Fulmer, G. R.; Miller, A. J. M.; Sherden, N. H.; Gottlieb, H. E.; Nudelman, A.; Stoltz, B. M.; Bercaw, J. E.; Goldberg, K. I. NMR Chemical Shifts of Trace Impurities: Common Laboratory Solvents, Organics, and Gases in Deuterated Solvents Relevant to the Organometallic Chemist. Organometallics 2010, 29, 2176-2179.

(53) Frisch, M. J.; Trucks, G. W.; Schlegel, H. B.; Scuseria, G. E.; Robb, M. A.; Cheeseman, J. R.; Scalmani, G.; Barone, V.; Mennucci, B.; Petersson, G. A.; Nakatsuji, H.; Caricato, M.; Li, X.; Hratchian, H. P.; Izmaylov, A. F.; Bloino, J.; Zheng, G.; Sonnenberg, J. L.; Hada, M.; Ehara, M.; Toyota, K.; Fukuda, R.; Hasegawa, J.; Ishida, M.; Nakajima, T.; Honda, Y.; Kitao, O.; Nakai, H.; Vreven, T.; Montgomery, J. A., Jr.; Peralta, J. E.; Ogliaro, F.; Bearpark, M.; Heyd, J. J.; Brothers, E.; Kudin, K. N.; Staroverov, V. N.; Keith, T.; Kobayashi, R.; Normand, J.; Raghavachari, K.; Rendell, A.; Burant, J. C.; Iyengar, S. S.; Tomasi, J.; Cossi, M.; Rega, N.; Millam, J. M.; Klene, M.; Knox, J. E.; Cross, J. B.; Bakken, V.; Adamo, C.; Jaramillo, J.; Gomperts, R.; Stratmann, R. E.; Yazyev, O.; Austin, A. J.; Cammi, R.; Pomelli, C.; Ochterski, J. W.; Martin, R. L.; Morokuma, K.; Zakrzewski, V. G.; Voth, G. A.; Salvador, P.; Dannenberg, J. J.; Dapprich, S.; Daniels, A. D.; Farkas, O.; Foresman, J. B.; Ortiz, J. V.; Cioslowski, J.; Fox, D. J. Gaussian 09, Revision D.01; Gaussian, Inc.: Wallingford, CT, 2013. 